IJHER International Journal of Humanities and Educational Research ISSN: 2757-5403

Volume 4, Issue 1, February 2022

Received: $27 / 11 / 2021$

Accepted: 06/01/2022

Published: 01/02/2022

\title{
THE LEVEL OF FEELING OF PSYCHOLOGICAL SECURITY AND ITS RELATIONSHIP TO SOME VARIABLES IN OMANI SOCIETY IN LIGHT OF THE CORONA CORRUPTION 19
}

\author{
Salim Bin Nasser Bin Saeed AL-KAHALI ${ }^{1}$ \\ Researcher, Sultanate of Oman \\ Khalfan Bin Salim Bin Abdullah AL-KAHALI 2 \\ Researcher, Sohar University, Sultanate of Oman
}

\begin{abstract}
The study aimed at identifying the level of psychological security well as to identify the relationship and its relationship to some variables in Omani society in light of the Corona pandemic 19. And also identifies the differences in the level of feeling of psychological security according to the variable of gender, nature of work, and age. The sample of the study consisted of (311) of them (157) males and (154) females. A questionnaire was applied to measure the level of feeling of psychological security, which included (20) items, distributed on two dimensions: the first dimension is satisfaction with life under the Corona pandemic and includes (10) items, and the second dimension psychological reassurance in light of the Corona pandemic and includes (10) paragraphs. The results of the study indicated that there is a high level of psychological security in the Omani society in light of the Corona Covid 19 pandemic. And the absence of statistically significant differences due to the gender variable and the age variable, while there were statistically significant differences in the variable nature of work for the benefit of employees. The study recommended the necessity of providing members of society with social and psychological skills that enhance positive feelings, and achieve their presence and their social and psychological interaction in light of the pandemic of Corona Coved 19 by employing workshops and divergent conferences using modern electronic technologies.
\end{abstract}

Key words: Psychological, Corona, Society.

http://dx.doi.org/10.47832/2757-5403.12.6

https://orcid.org/0000-0002-7462-1649

KHALFAN.ALKAHALI@moe.om, https://orcid.org/0000-0002-3422-7364

www.ijherjournal.com 


\title{
مستوى الثعور بالأمن النفسي وعلاقته ببعض المتغيرات في المجتمع العماني في ظل جائحة كورونا كوفيد 19
}

\author{
سالم بن ناصر بن سعيد الكحالي \\ الباحث، سلطنة عمان \\ خلفان بن سالم بن عبد الله الكحالي

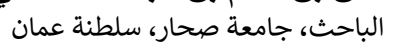

هدفت الدراسة إلى الكثف عن مستوى الثعور بالأمن النفسي وعلاقته ببعض المتغيرات في المجتمع العماني في ظل

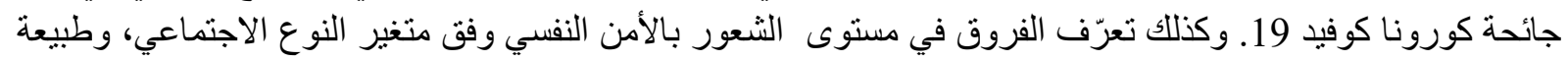

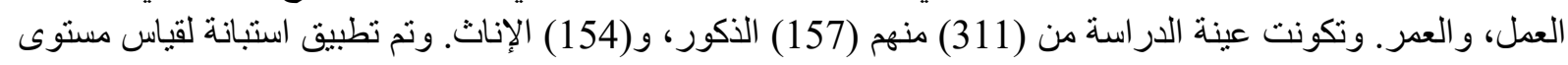

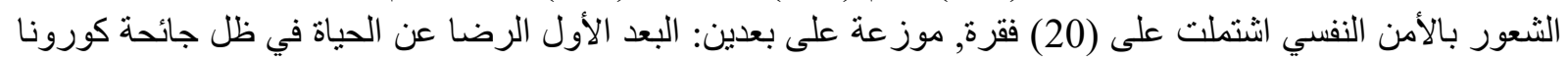

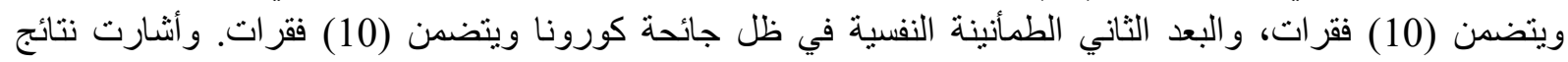

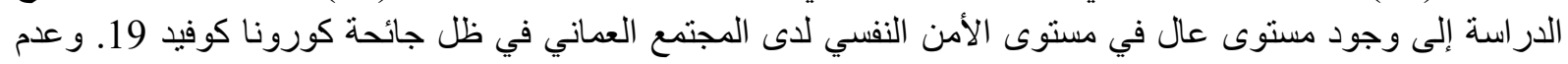

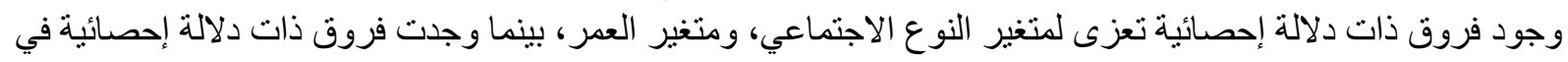

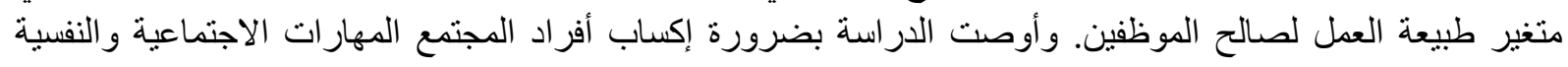

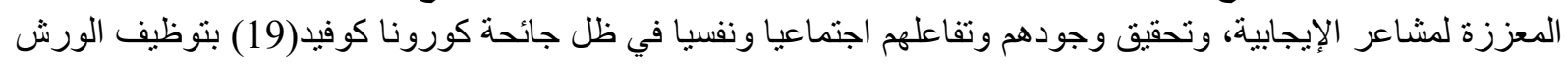

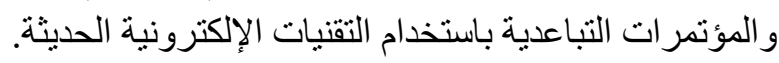
الكلمات المفتاحية: الأمن النفسي، جائحة كورونا، دلالة إلفائة الحصائية.

\section{المقدمة:}

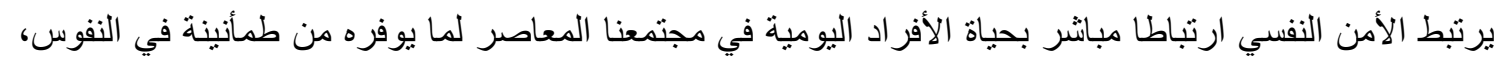

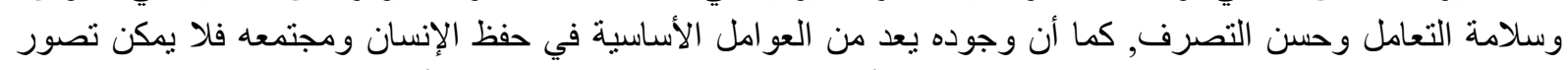

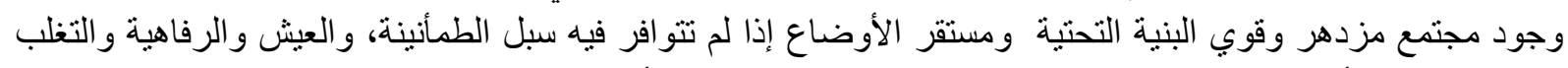

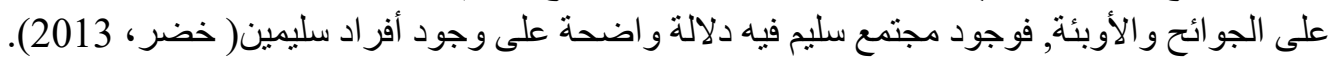

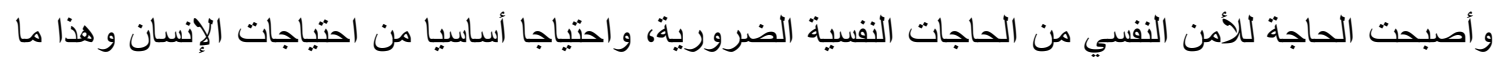

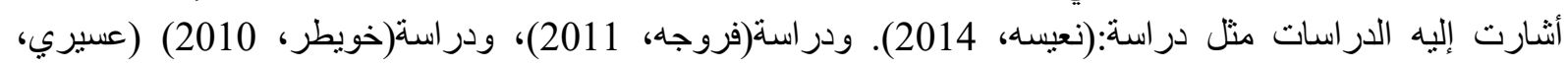

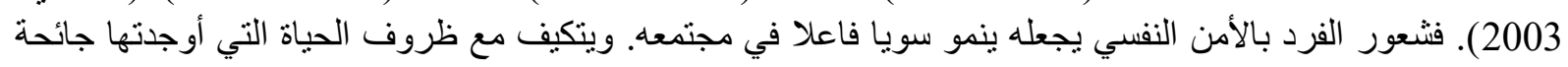

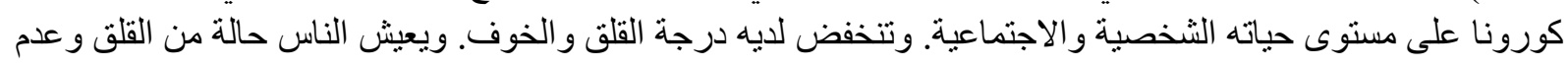

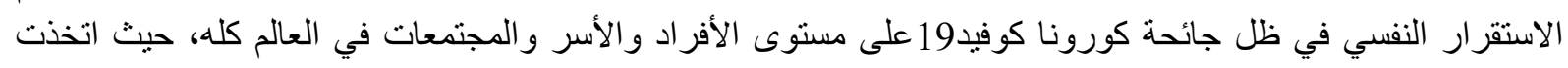
الدول إجر اءات وتدابير احتر ازية للحد من انتشاره.

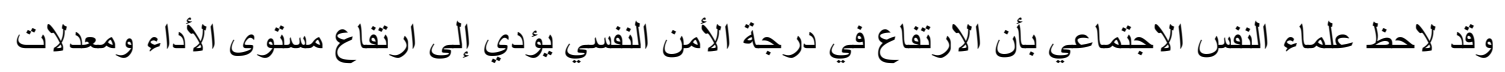

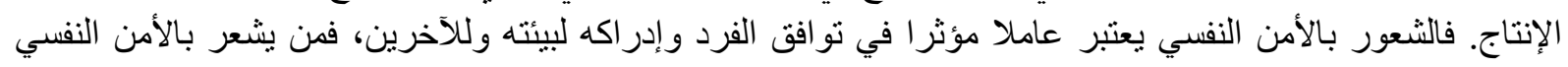

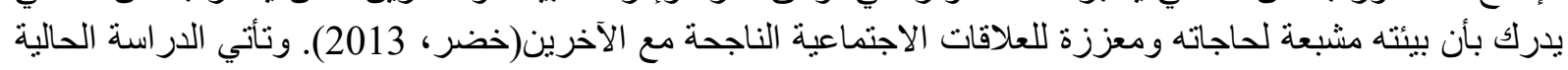

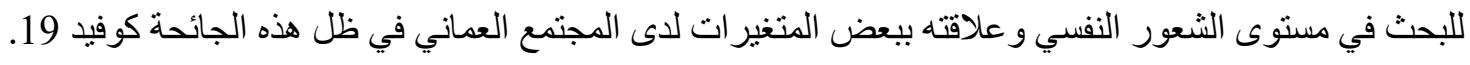

مثكلة الدراسة:

تتأثر حياة الناس ومصالحهم بجائحة كورونا، فقد توقفت مناشط الحياة الاجتماعية والتعليمية والاقتصادية،

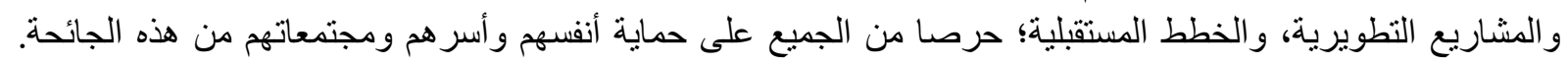




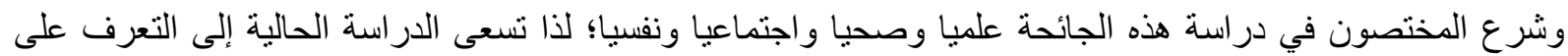

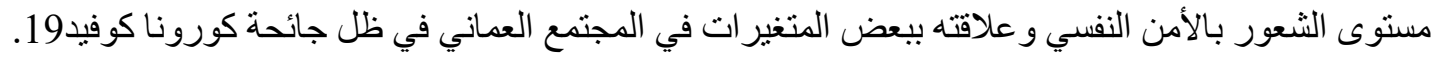
و التي تتحدد في السؤال الرئيس الآتي: ما مستوى الثعور بالأمن النفسي في المجتمع العماني في ظل فل جائحة

كورونا(كو فيد 19). وتتفرع منه الأسئلة الآتية:

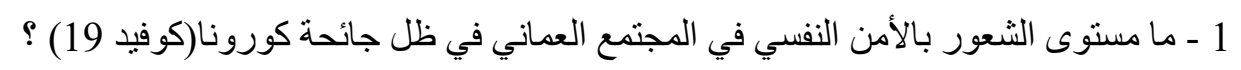

2 - هل توجد فروق ذات دلالة إحصائية في مستوى الثعور بالأمن النفسي في المجتمع العماني في ظل جائحة

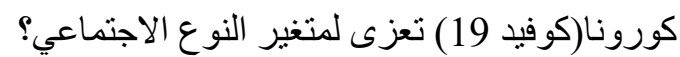

3 - هل توجد فروق ذات دلالة إحصائية في مستوى الثعور بالأمن النفسي لدى المجتمع العماني في ظل جائحة كورونا

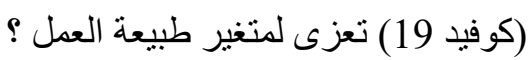

4 - هل نوجد فروق ذات دلالة إحصائية في مستوى الثعور بالأمن النفسي لدى المجتمع العماني في ظل جائحة كورونا

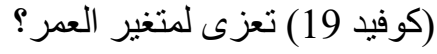

أهداف الاراسة:

1 - التعرف على مستوى الثعور بالأمن النفسي في المجتمع العماني في ظل جائحة كورونا كوفيد19.

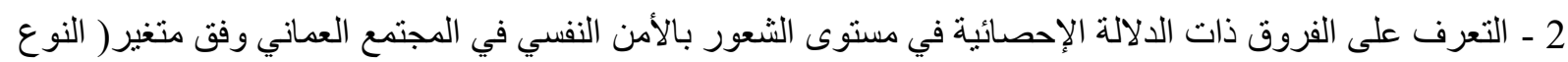
الاجتماعي، وطبيعة العمل، و العمر ).

أهمية الار استة: تتجلى أهمية الدراسة في الآتي: التيد

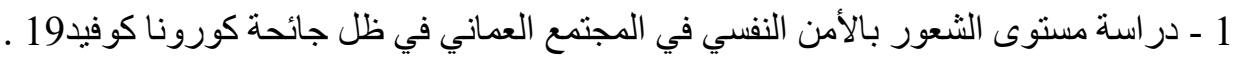

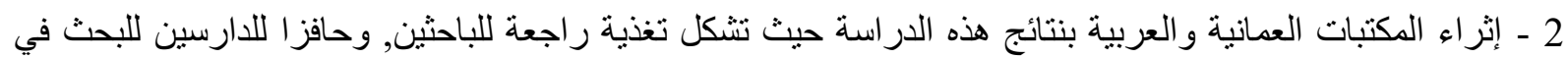
كيفية توظيف الأمن النفسي في رفع معدلات المشاركة التربة الفاعلة في التنمية المجتمعية. 3 - تزويد المختصين وصانعي القرار بعدد من التوصيات و المقترحات لتعزيز الأمن النفسي في المجتمع العماني.

حدود الار اسةة: الحدود الموضوعة: مستوى الثعور بالأمن النفسي في المتمع العماني في ظل جائحة كورونا. الحدود المكانية : اقتصرت الدر اسة الحالية على محافظات سلطنة عمان.

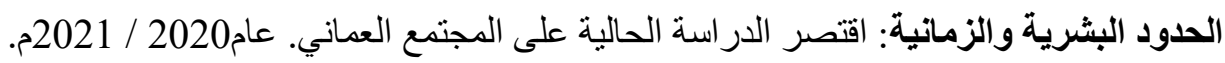

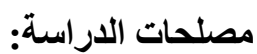
الأمن النفسي :"هو شعور الفرد بأنه محبوب ومتقبل من الآخرين له مكان بينهم، ويدرك أن بيئته صديقة ودودة غير

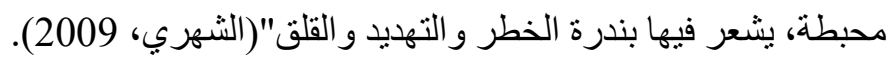
التعريف الإجرائي: الدرجة التي يحصل عليها أفر اد العينة من خلال فقرات الاستبانة المعدة لغرض التهرة الدراسة.

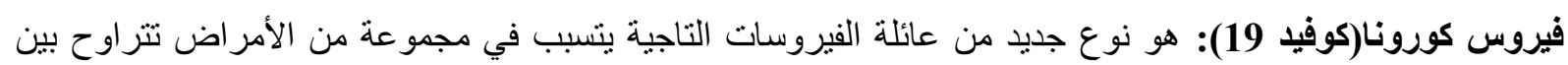

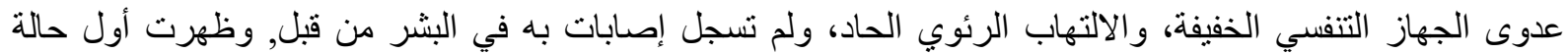

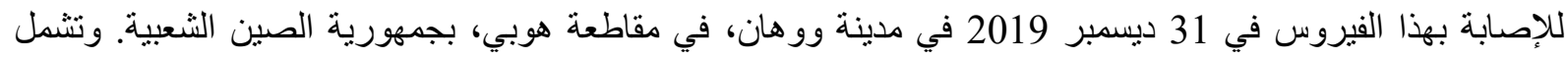

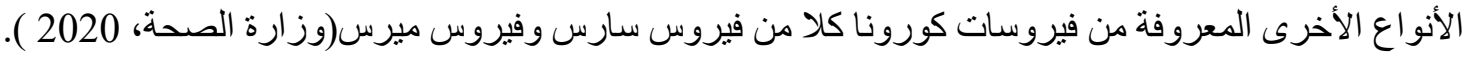




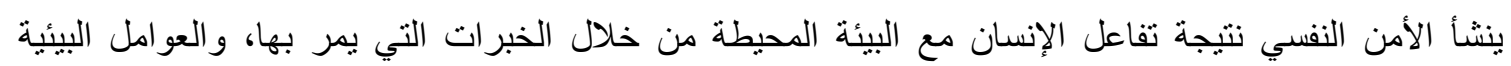

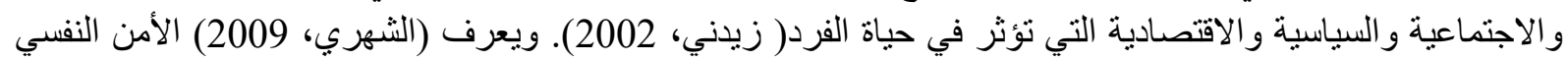

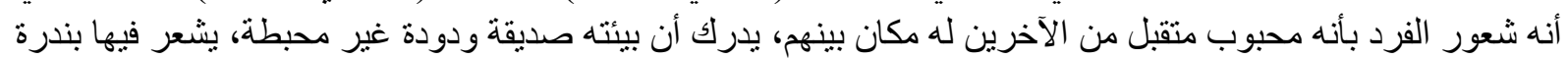
الخطر و التهديد و القلق. النه.

والأمن النفسي: هو الطمأنينة النفسية أو الانفعالية وهو الأمن الثخصي أو أمن كل فرد على حده، وهو والثو حالة يكون

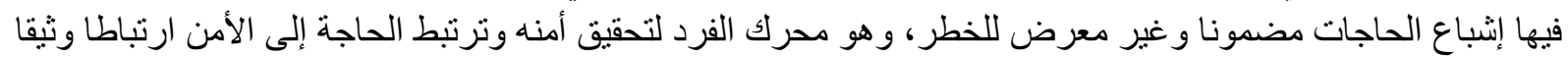

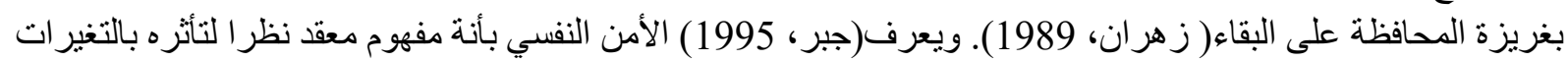

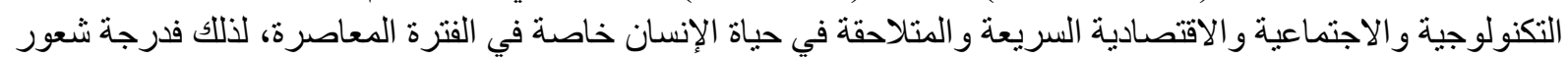

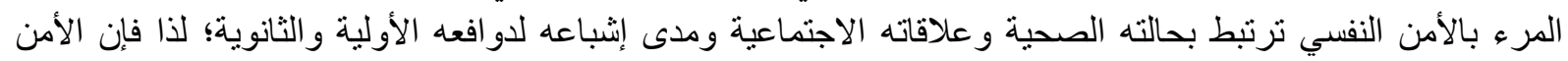

$$
\text { النفسي ينكون من جانبيين هما: }
$$

ـ ـ داخلي: يتمثل في عملية التو افق النفسي مع الذات أب قدرة المرء على حل الصر اعات التي تواجهه وتحمل الأزمات والحرمان. - ـ ـارجي: يتمثل في عملية التكيف الاجتماعي، بمعنى قدرة المرء على التلاؤم مع البيئة الخارجية و التوفيق بين المطالب الغريزية و العالم الخارجي و والأنا الأعلى.

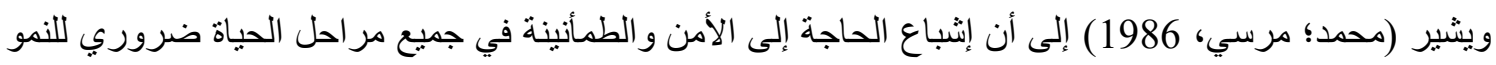

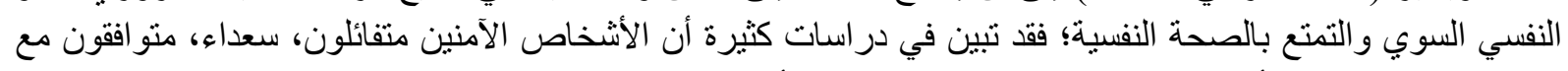

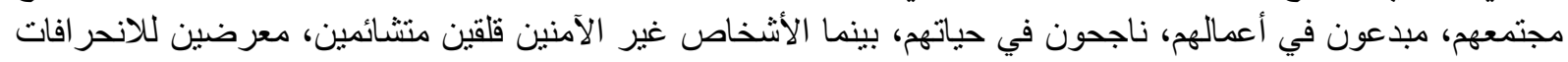
النفسية و الأمر اض السيكوسو في أعبونية.

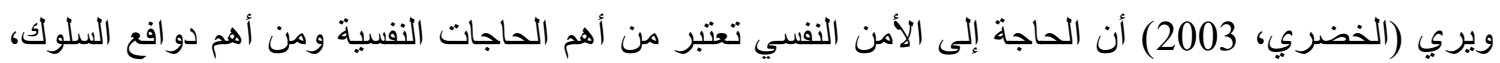

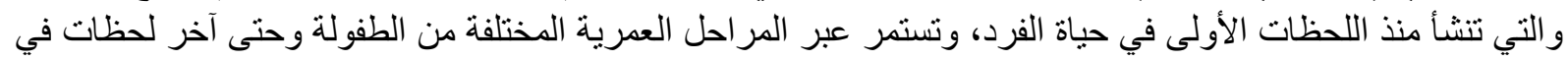

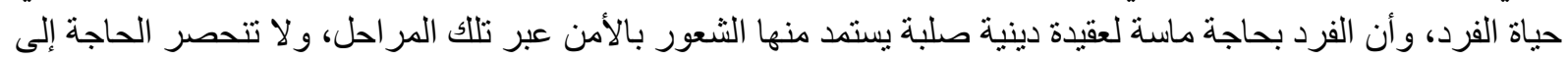

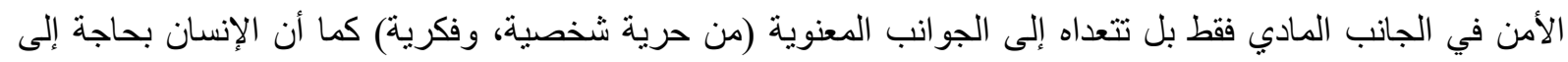
الأمن في شنى أماكن تو اجده في البيت، و العمل، و المدرسة.

\section{عوامل الأمن النفسي وفقدانه:}

1 - الشعور بالحب مقابل الحرمان من الحب: فالشعور بالحب يلعب دورا كبير الفي في نشأة شخصية الإنسان وفي تشكيل مفهوم الذات لدية، وبالتالي في شعوره بالأمن النفسي بحيث يؤدي إحباط الحاجة إلى الحب إلى إلى تدهور الحالة النفسية و الجسمية للإنسان(عثمان، 2001).

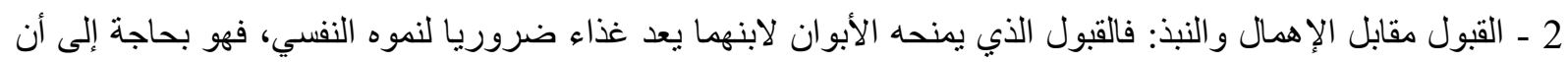

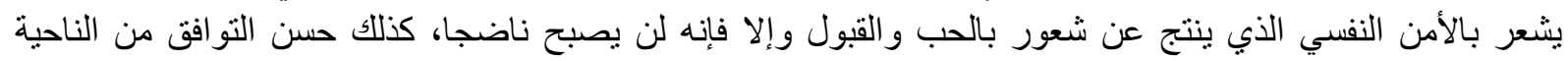

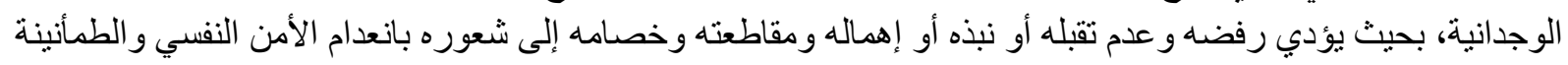

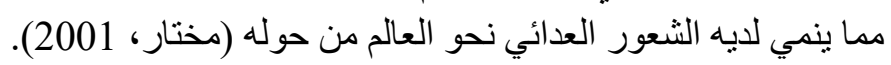

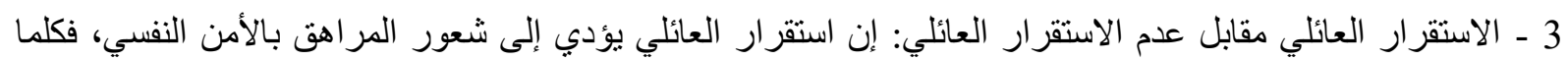

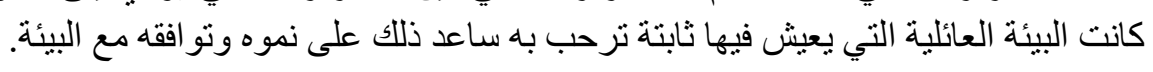


تناولت عدد من النظريات الأمن النفسي وربطت تفسيره بعده عو امل، ومن تلك النظريات:

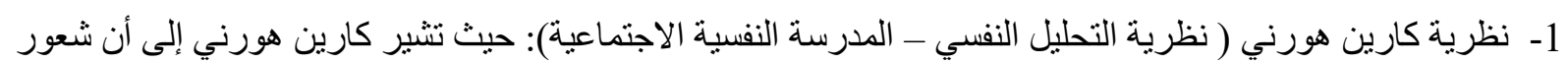

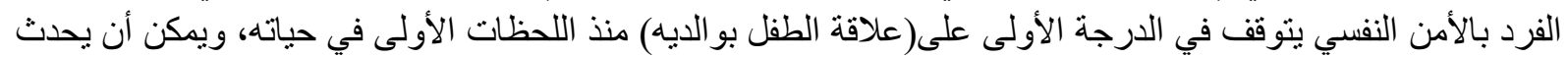

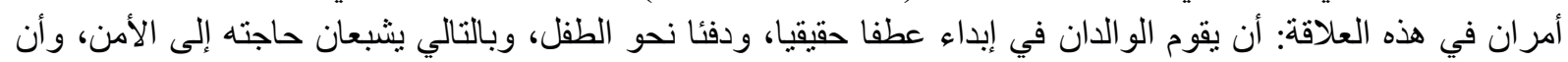

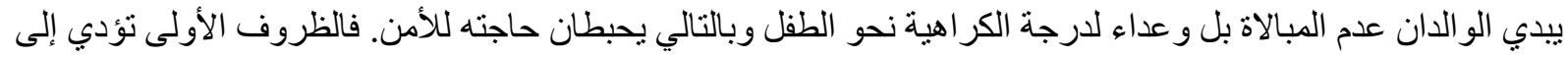

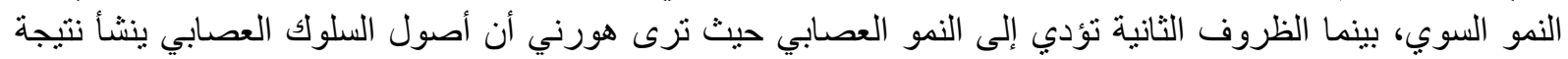

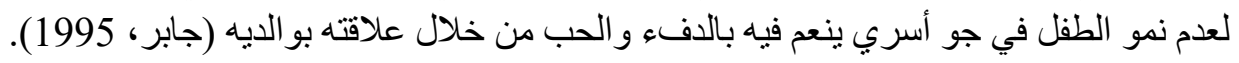

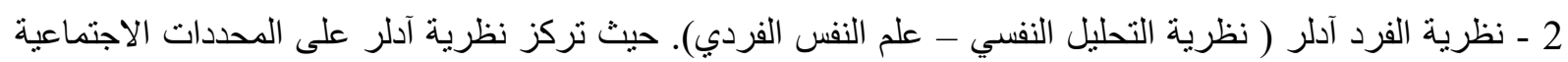

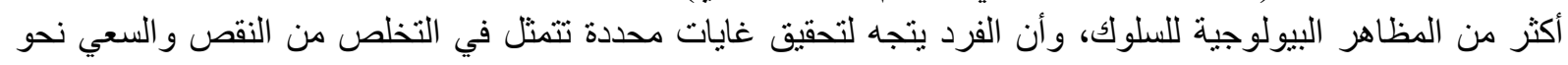

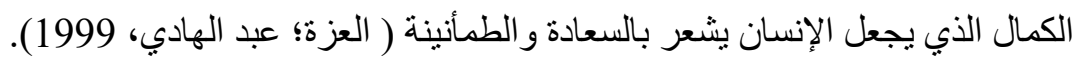

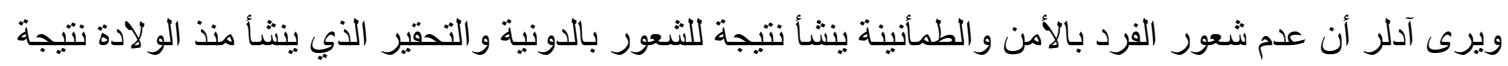

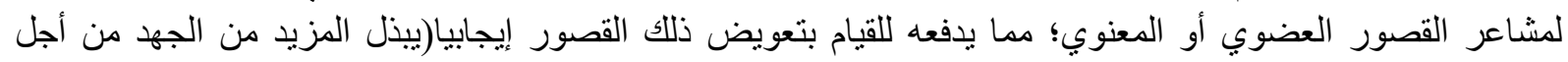

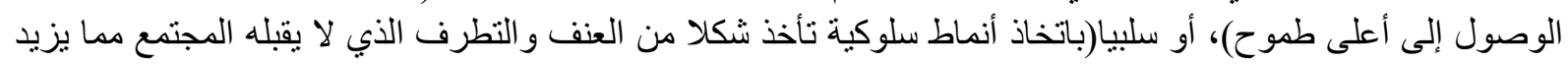

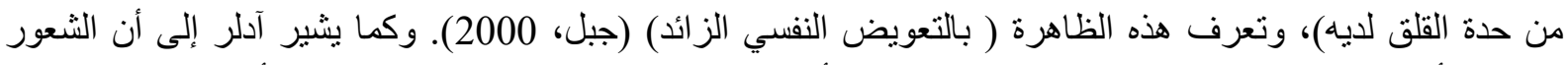
بانعدام الأمن يعود إلى نوع التربية التي يتلقاها الطفل في أسرته في مرحلة الطفولة والتي تنؤثر في نشأة القلق النفسي (آغا،

1988)

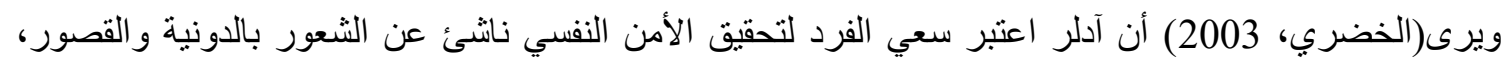

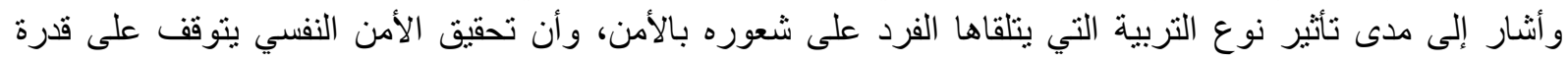

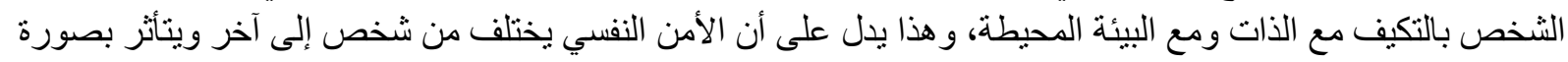

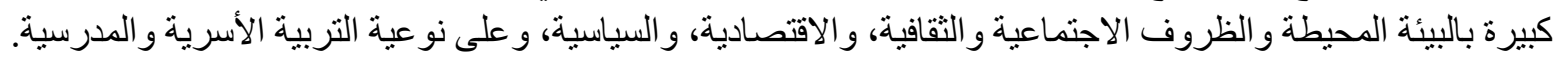

المشكلات التي تؤثر على الثعور بالأمن النفسي:

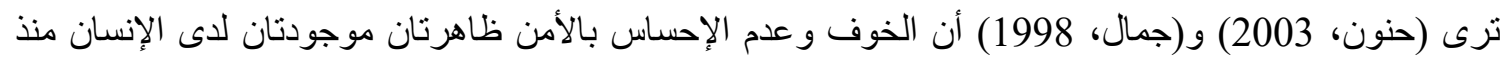

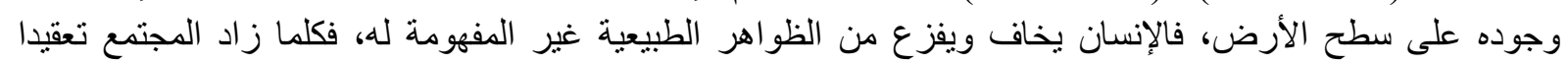

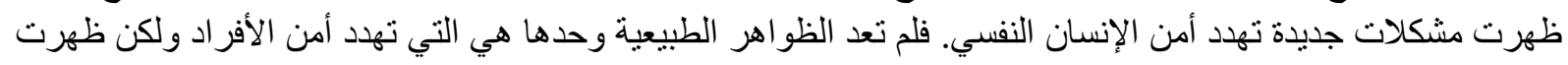

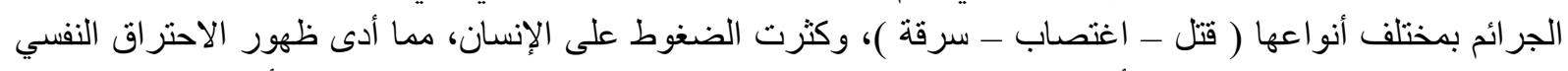

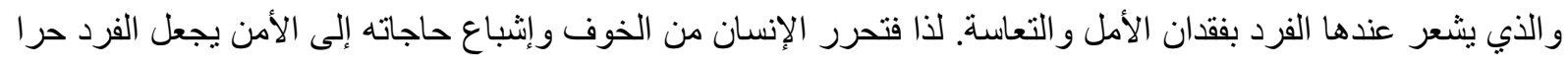

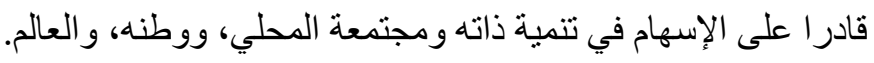

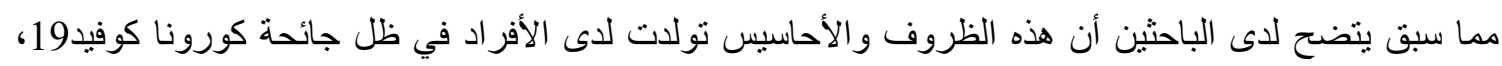

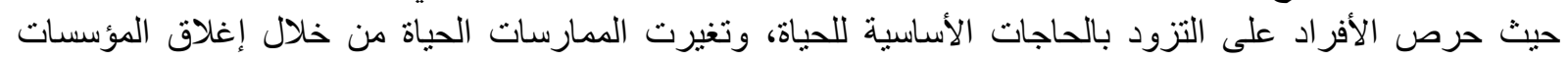

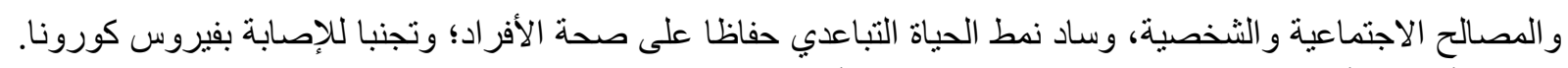

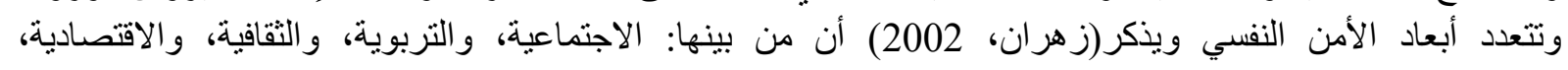

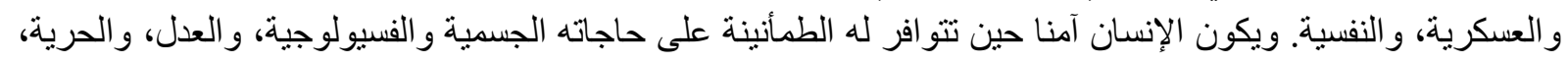

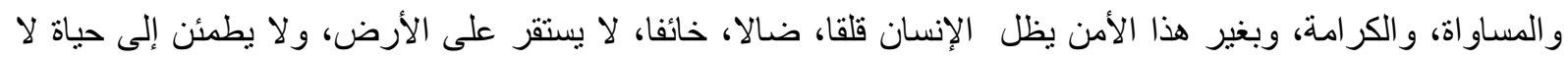
سيما في ظل الظروف التي أوجدتها هذه الجائحة. 
الاراسات السابقة العربية والأجنبية

تنو عت الدر اسات العربية والأجنبية التي تناولت دراسة الثعور بالأمن النفسي، ويعرض لكم هذا الفصل الدراسات

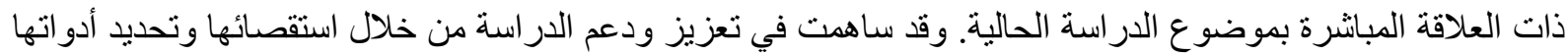

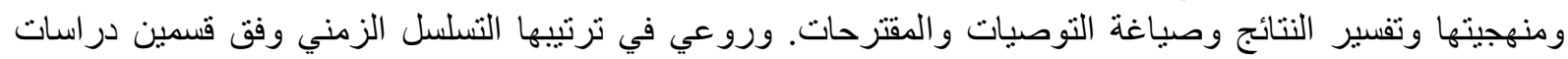
عربية، ودر اسات أجنيية.

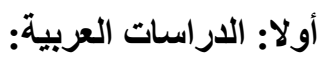

هدفت در اسة (حليم، 2017) إلى تحديد الفروق بين الذكور و الإناث في الطمانينة الانفعالية لاىى طلبة الجامعة.

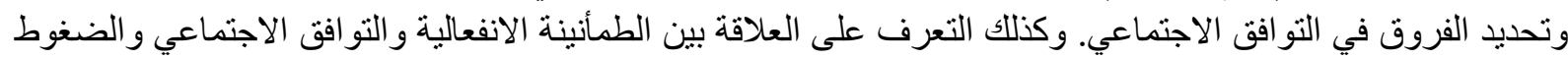

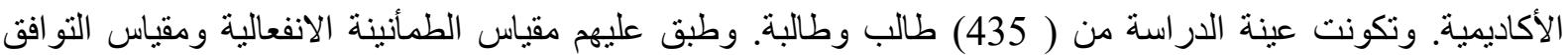

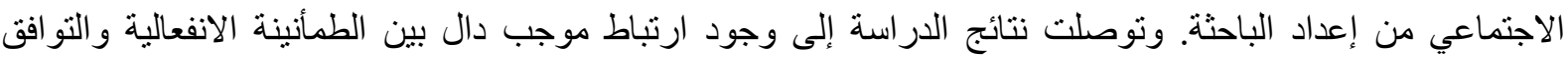

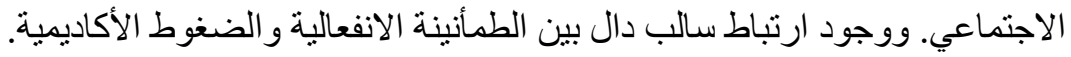

و هدفت دراسة (جاسم؛ خليل، 2009) إلى التعرف على الأمن النفسي وعلاقته بالثعور بالوحدة النفسية لدى عينة

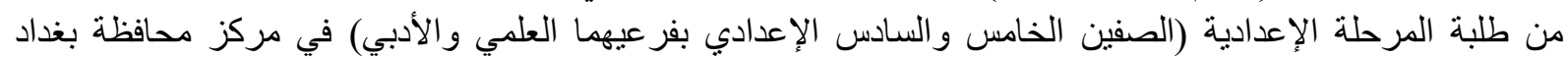
الرصافة الأولى. وتكونت عينة الدر اسة من (1500) طالب وطالبة نم اختيار هم بالطريقة الطبقية العشو ائية موزعين وفق الإنق

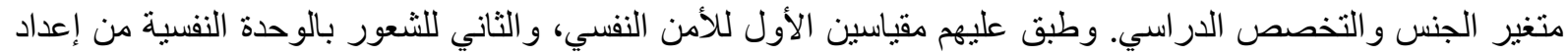

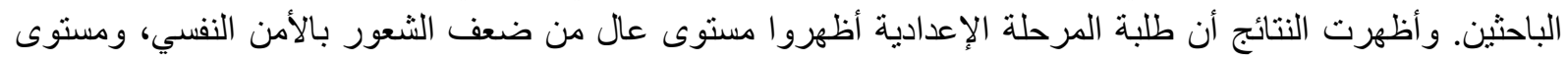

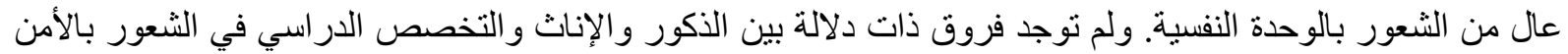

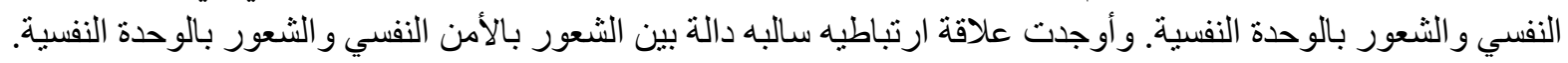

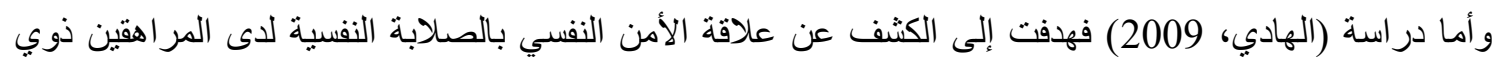

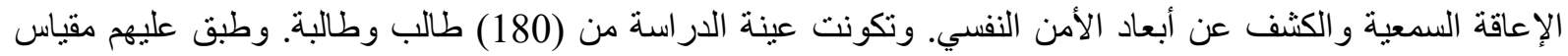

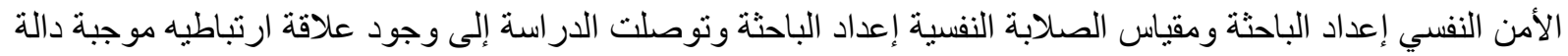

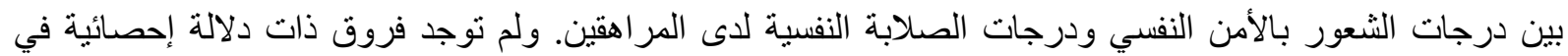

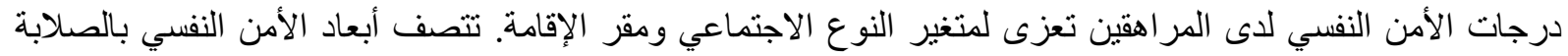

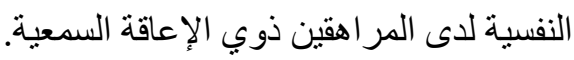

وفي در اسة (قاسم؛ سلطان، 2008) و التي هدفت إلى التعرف على التع مستوى الأمن النفسي لاى طالبات كلية التربية للبنات، وتعرف الفروق في مستوى الأمن النفسي بحسب التخصص الدراسي. وتكونت عينة الدراسة من (45) طالبة.

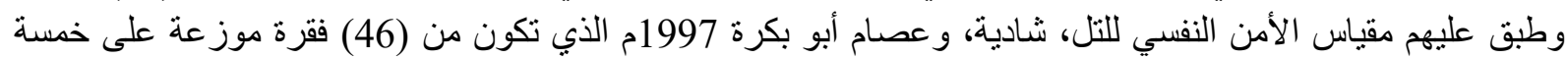

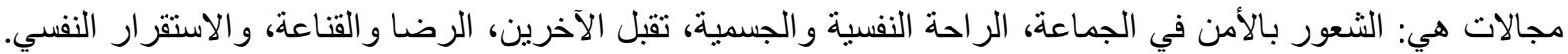

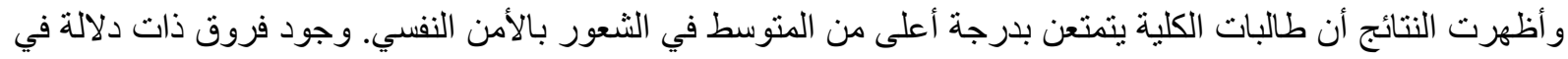

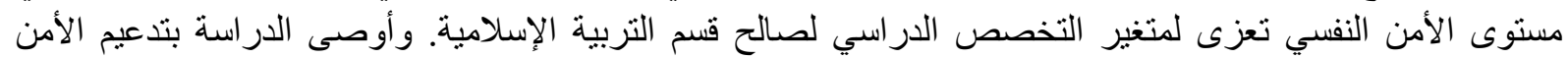
النفسي في سلوك الطالبات و إقامة الندو ات و الحلقات الدر اسية للتأكيد على الأمن النفسي.

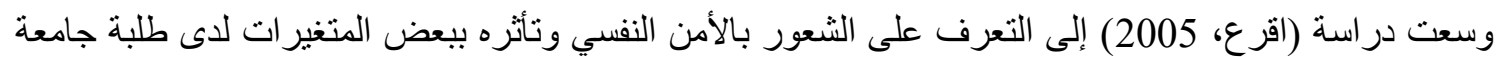

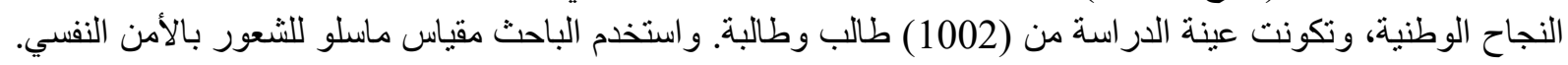

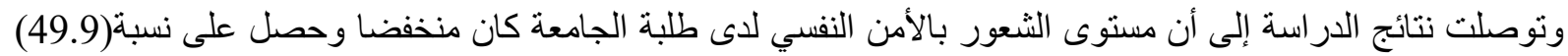

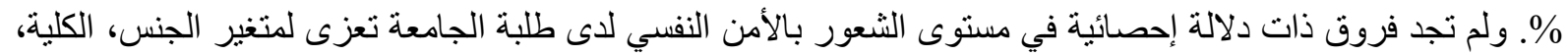
مكان السكن، المعدل التر اكمي، و المستوى التعليمي.

أما دراسة (عبد الحميد، 2004) فهدفت إلى بحث إساءة المعاملة والأمن النفسي لدى على عينة من تلاميذ المدرسة

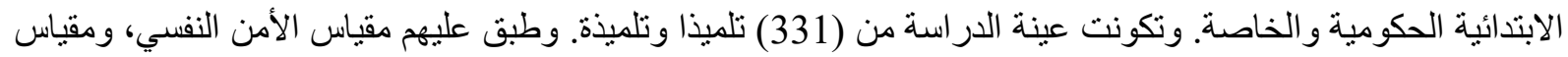

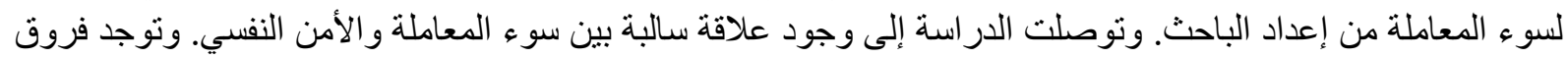

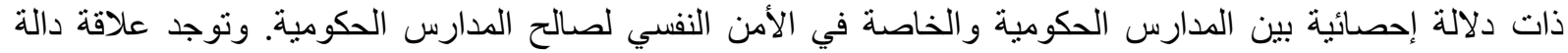
إحصائية بين المستوى الدر اسي ومستوى الثنعور بالأمن النفسي. 
و هدفت در اسة (العقيلي، 2004) إلى الكثف عن العلاقة الارتباطية بين الاغتر اب والأمن النفسي لدى طلبة جامعة

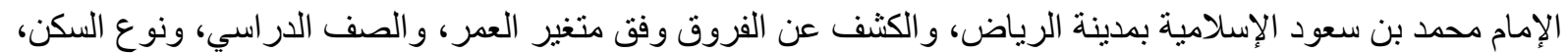

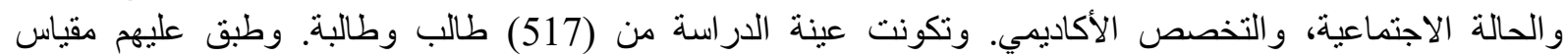

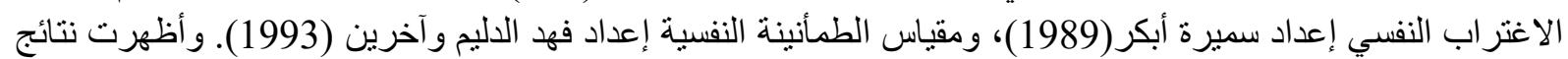

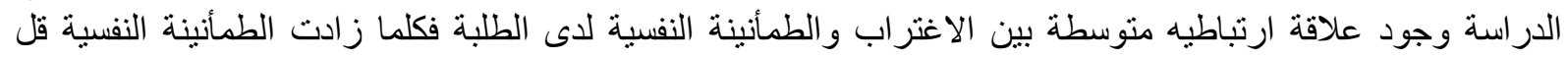

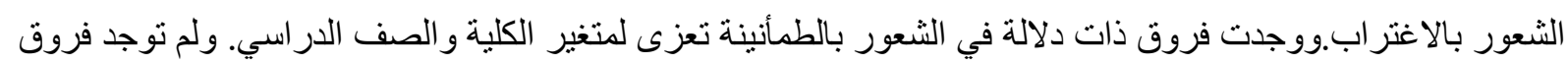

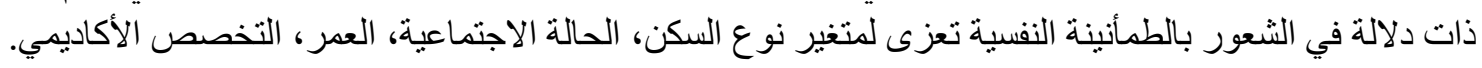

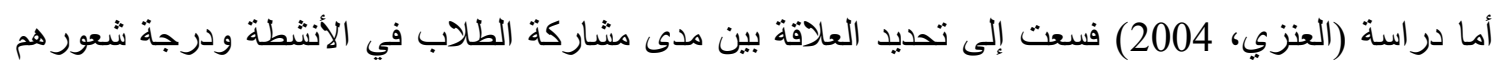
بالأمن النفسي والاجتماعي المدرسي. والكثف عن الفروق في في درجة الكئ الثعور بالأمن النفسي والاجتماعي بين الطلاب

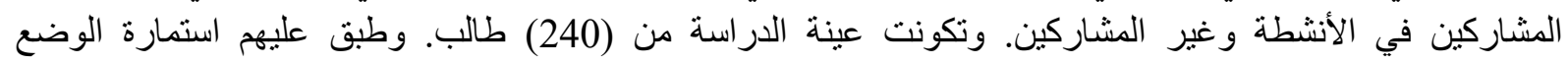

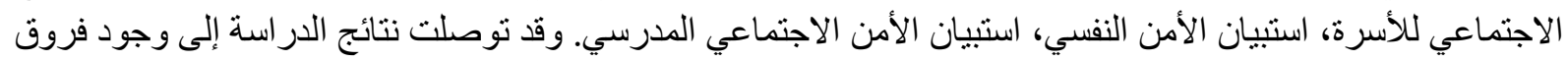

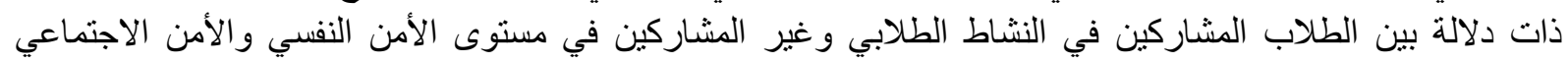

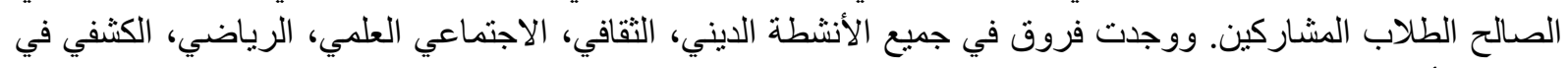
مستوى الأمن النفسي لصالح الطلاب المشاركين.

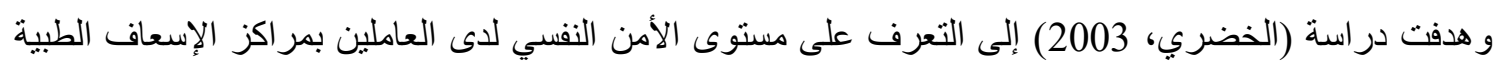

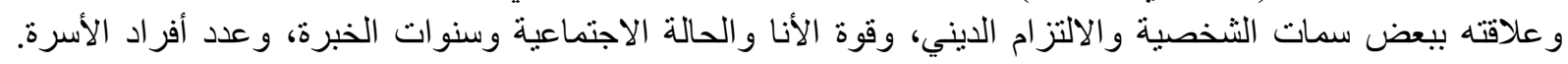

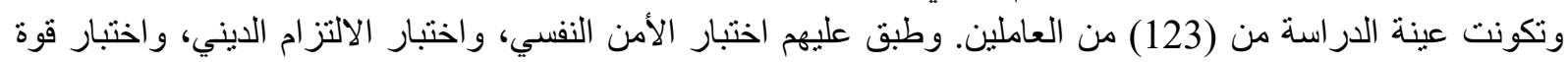

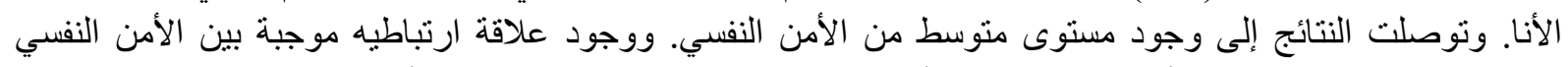

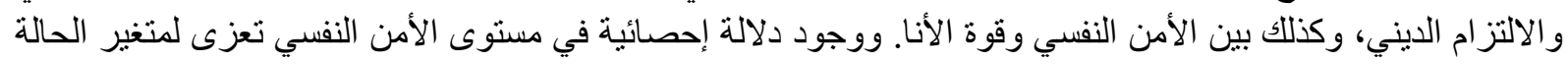

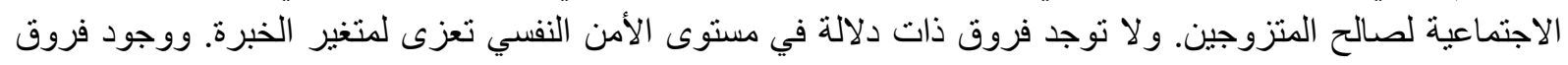

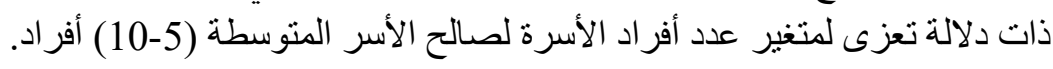

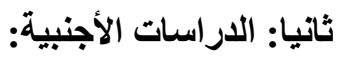

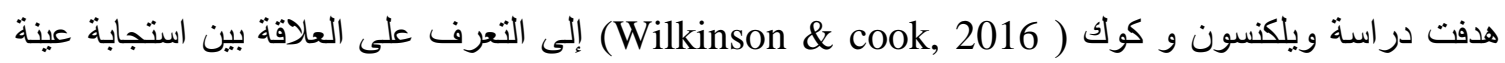

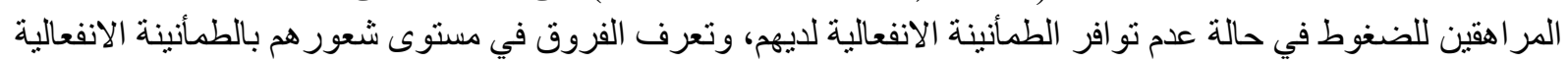

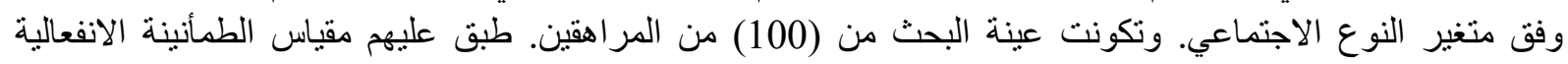

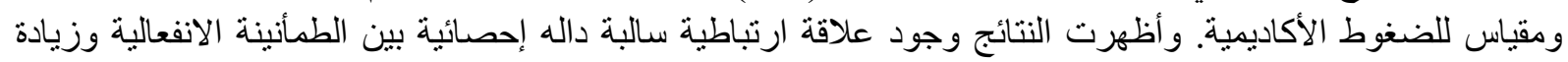

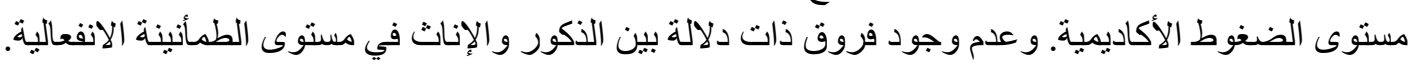

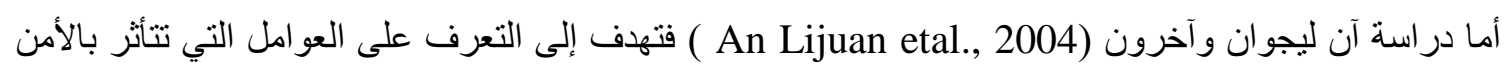

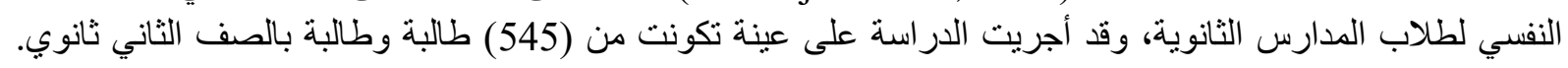

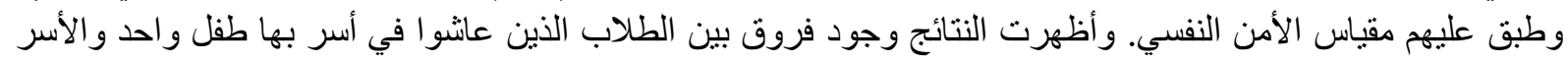

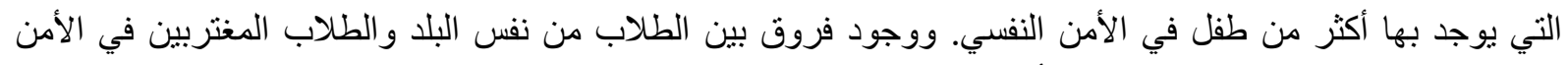
النفسي. ووجود فروق بين الجنسين في الأمن النفسي. و هدفت دراسة فورمان وديفيس (Forman, Davies, 2005) إلى التعرف على على العلاقة بين عدم الاستقرار

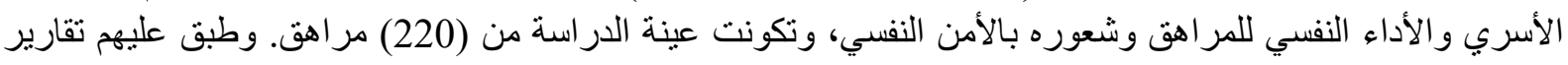

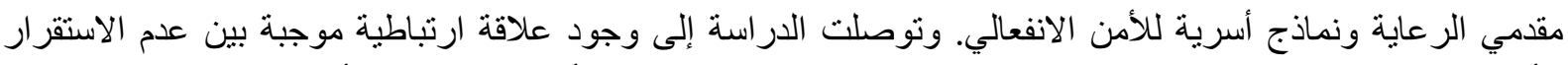

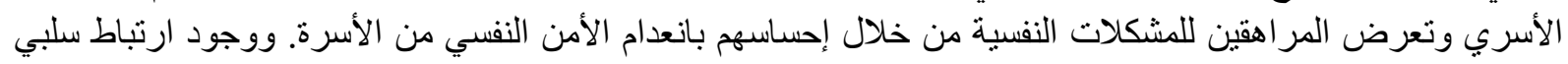

بين عدم الاستقرار الأسري و الصعوبات الو الدية و المستويات المنخفضة للأمن النفال النفسي المدركة في الأسرة.

وبينت دراسة كيرنز وآخرون ( Kerns, etal, 2001 التي هدفت إلى التعرف على التى على علاقة الأمن النفسي للأطفال

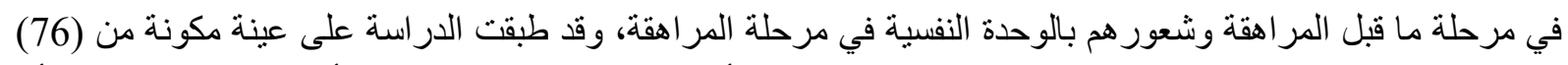

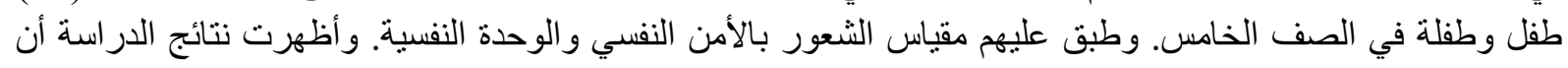
الأطفال الذين يشعرون بالأمن النفسي كانوا أكثر تحكما في الضغوط ولالديهم نظرة إيجابية نحو ذو اتهم و الآخرين و العالم. 
التعقيب على الاراسات السابقة:

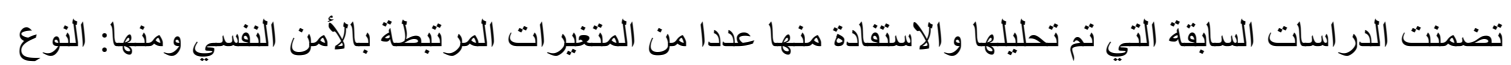

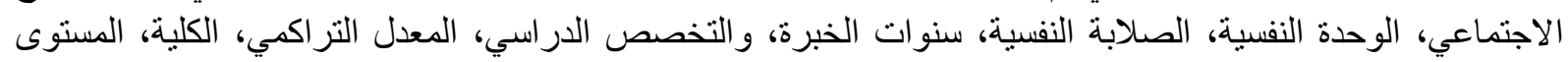

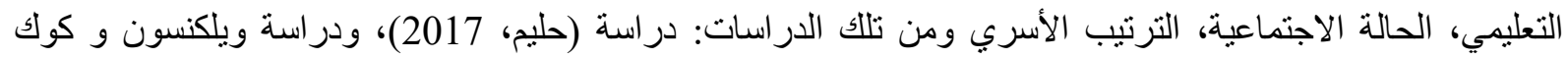

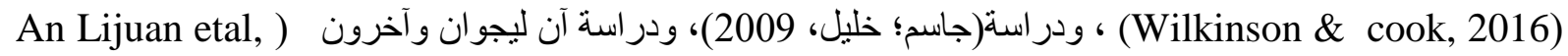

2004)، ودراسة (عبد الحميد، 2004).

استهدفت الدراسات السابقة مجتمعات متنوعة فتعددت العينات فمنها: طبقت على على طلبة الجامعات و الكليات مثل:

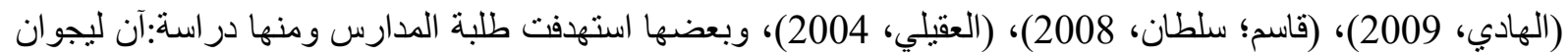
و آخرون (An Lijuan etal, 2004)، (العنزي، 2004)، (ليفي، (2004)، كيرنز وآخرون (Kerns, etal, 2001)،

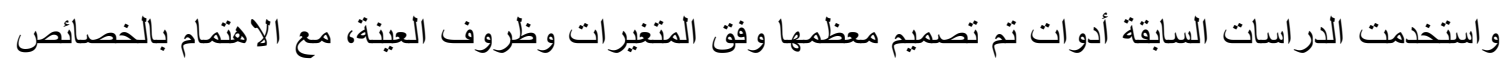

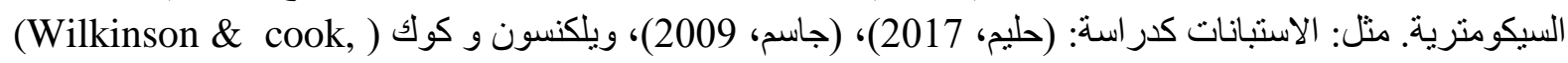

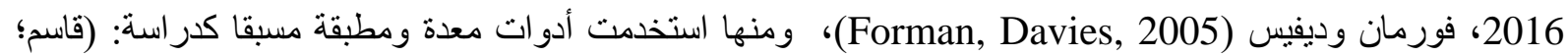

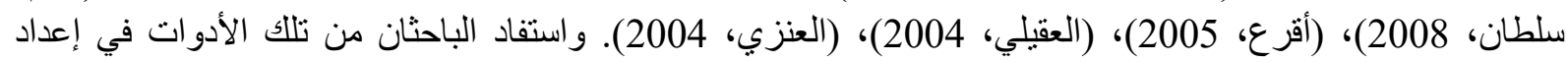
وتصميم أداة الدراسة الحالية وتحقيق الخصائص السيكومترية.

وتتوعت نتائج الدراسات السابقة فأنثارت بعض الدراسات إلى وجود مستوى منخفض اللشعور بالأمن النفسي مثل ودئل

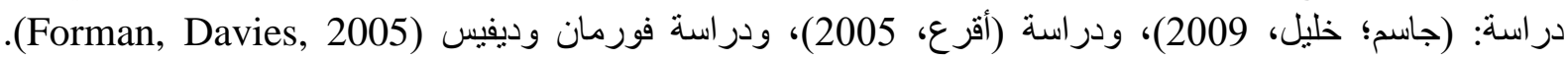

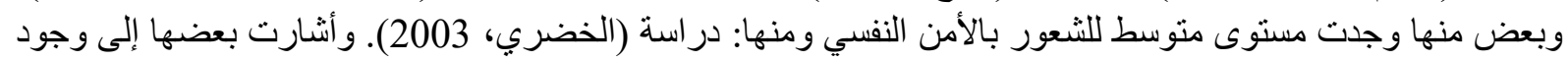

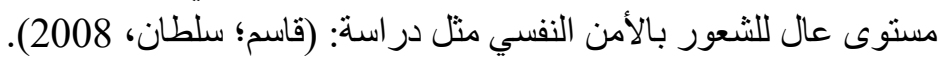

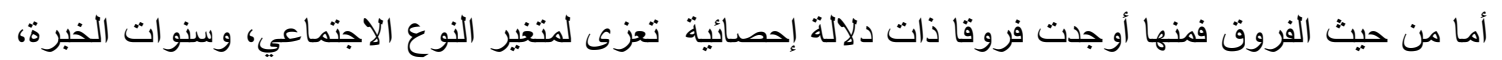

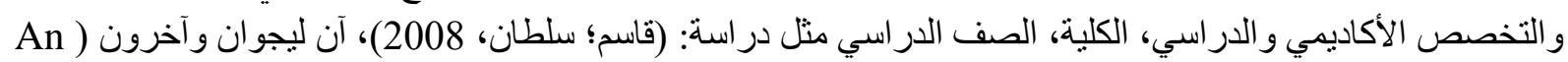

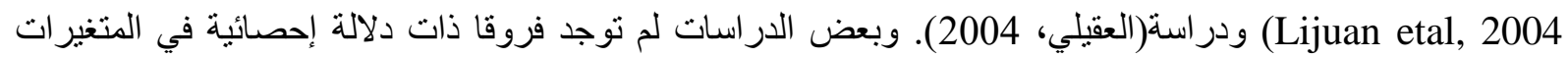

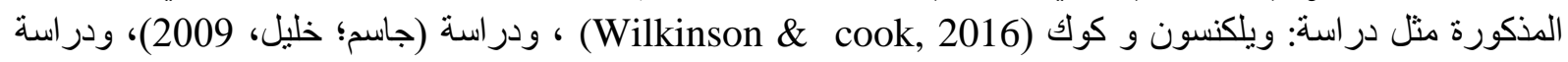
(الهادي، 2009)، ودر اسة (الخضري، ونس 2003).

وتمت الاستفادة بعد الاطلاع على الدراسات السابقة وتحليلها في إعداد منهجية الدراسة الحالية، والية، وتصميم الاستبانة

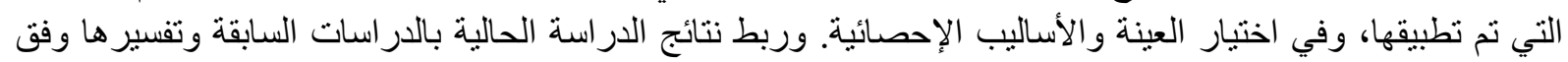

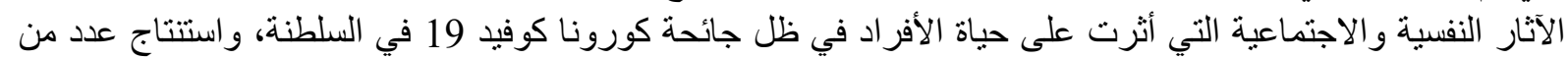

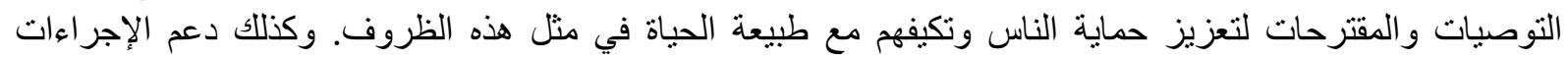

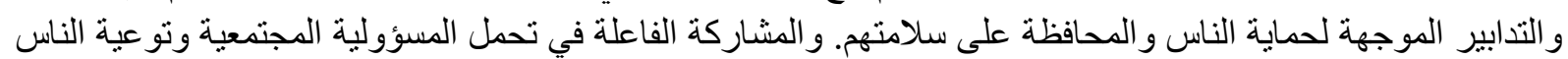
بخطورة فيروس كورونا وسبل الحماية والمحافظة على الصحة العامة على المستوى العائلي والمجتمعي و على مستوى السلطنة. 
اعتمدت الدراسة الحالية على المنهج الوصفي التحليلي لجمع البيانات التي تساعد على الكثنف عن مستوى الثنعور

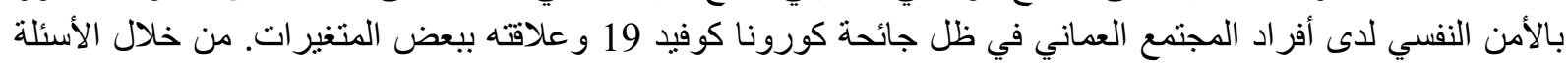
الموجهة لعينة الدر اسة، و أهداف الدر استة الحالية.

أولا: مجتمع وعينة الدراسة:

تكون مجتمع الدر اسة من المو اطنين و المقيمين في سلطنة عمان، وتكونت عينة الدراسة الفعلية من (311) فرد منهم (154) إناث و(157) ذكور، وتم اختيار هم بطريقة عشو ائية.

ثانيا: أداة الاراسة:

بعد الاطلاع على الأدبيات و الدر اسات السابقة في مجال الأمن النفسي و المتغير ات المرتبطة به، تم إعداد وتصميم

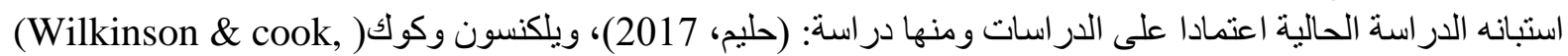

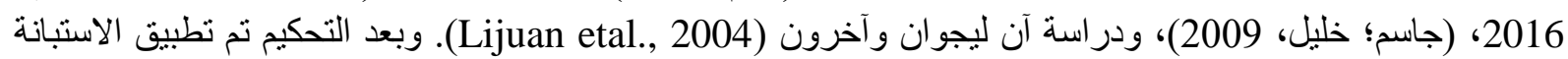

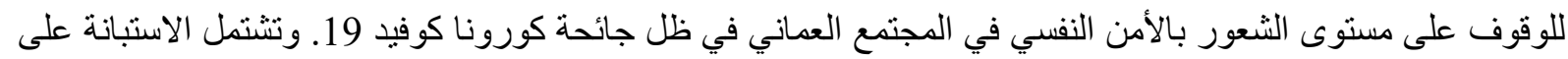

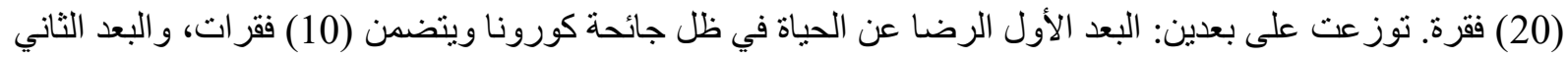

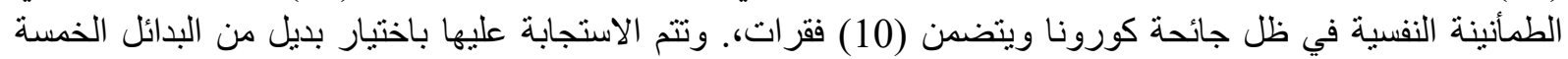

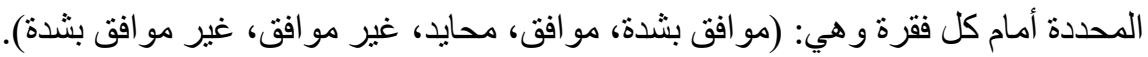

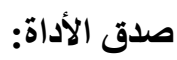

تحقيقا للخصائص السيكومترية في الدراسة الحالية، صدق الأداة فقد تم عرضها على عدد من من المختصين في علم

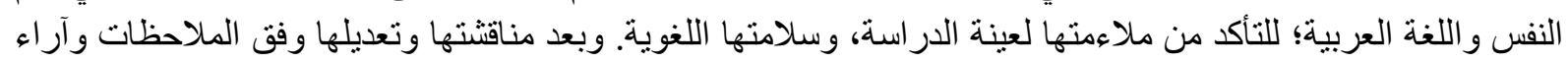

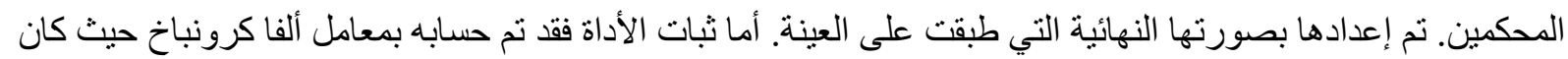

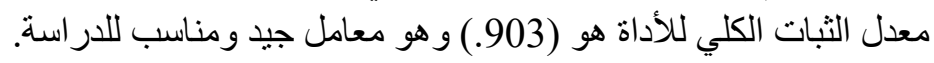

تطبيق أداة الاراسة:

بعد إعداد الاستبانة بصورتها النهائبة, شرع الباحثان في تطبيق الدراسة على العينة إلكترونيا, ونم تقديم شرح

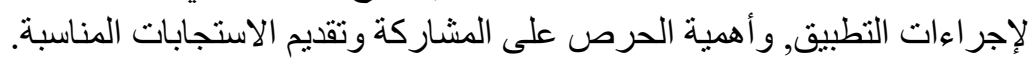

الأساليب الإحصائية:

استخدمت الاراسة الحالية الوسائل الإحصائية الآتية:

1 - المتوسطات الحسابية و الانحر افات المعيارية.

2 ـ الاختبار التائي لمجمو عتين مستقلتين لتعرف الفروق بين متغير ات الدر اسة الحالية.

3 - تحليل التباين الأحادي ( ANOVA) لتحديد الفروق ودلالتها الإحصائية. 
الفصل الخامس

نتائج الدراسة وتفسيرها

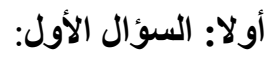

" ما مستوى الثعور بالأمن النفسي في المجتمع العماني في ظل جائحة كورونا(كوفيد 19)"؟ وللإجابة عن السؤال

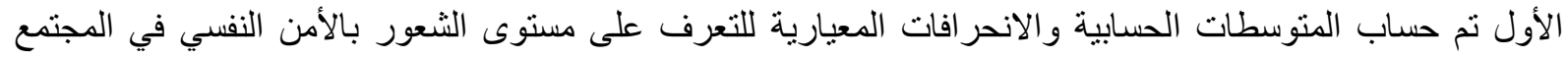

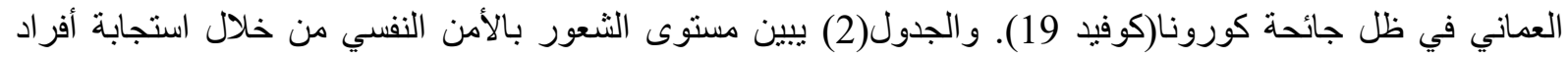

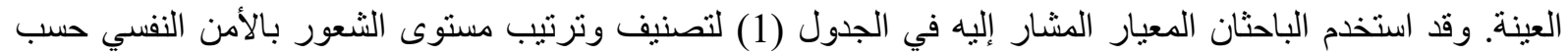

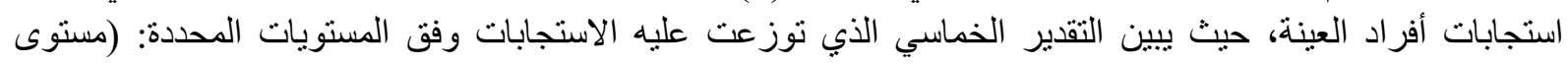

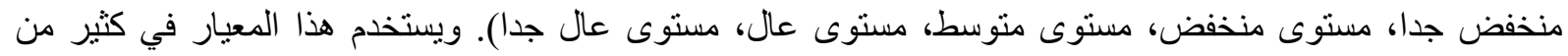

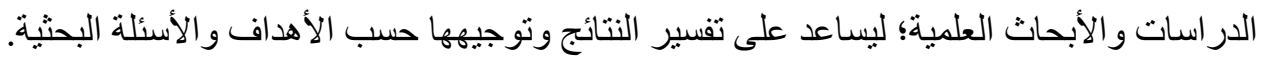

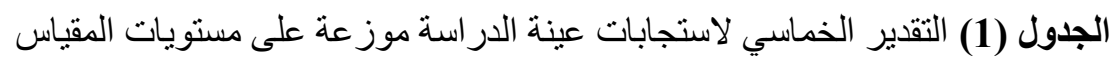

\begin{tabular}{|c|c|c|c|}
\hline \multirow[t]{2}{*}{ المستو يات } & \multirow[t]{2}{*}{ المدى } & مقياس الوعي & \multirow[t]{2}{*}{ 5 } \\
\hline & & التقدير & \\
\hline مستوى منخفض جذا & $1.79-1.00$ & قلبلة جدا & 1 \\
\hline مستوى منخفض & $2.59-1.80$ & قليلة & 2 \\
\hline مستوى منوسط & $3.39-2.60$ & متوسطة & 3 \\
\hline مستوى عال & $4.19-3.40$ & عالية & 4 \\
\hline مستوى عال جدا & $5.00-4.20$ & عالية جدا & 5 \\
\hline
\end{tabular}

جدول (2) المتوسطات الحسابية والانحر افات المعيارية لاستجابات العينة حول مستوى الثعور بالأمن النفسي وترتيب الأبعاد

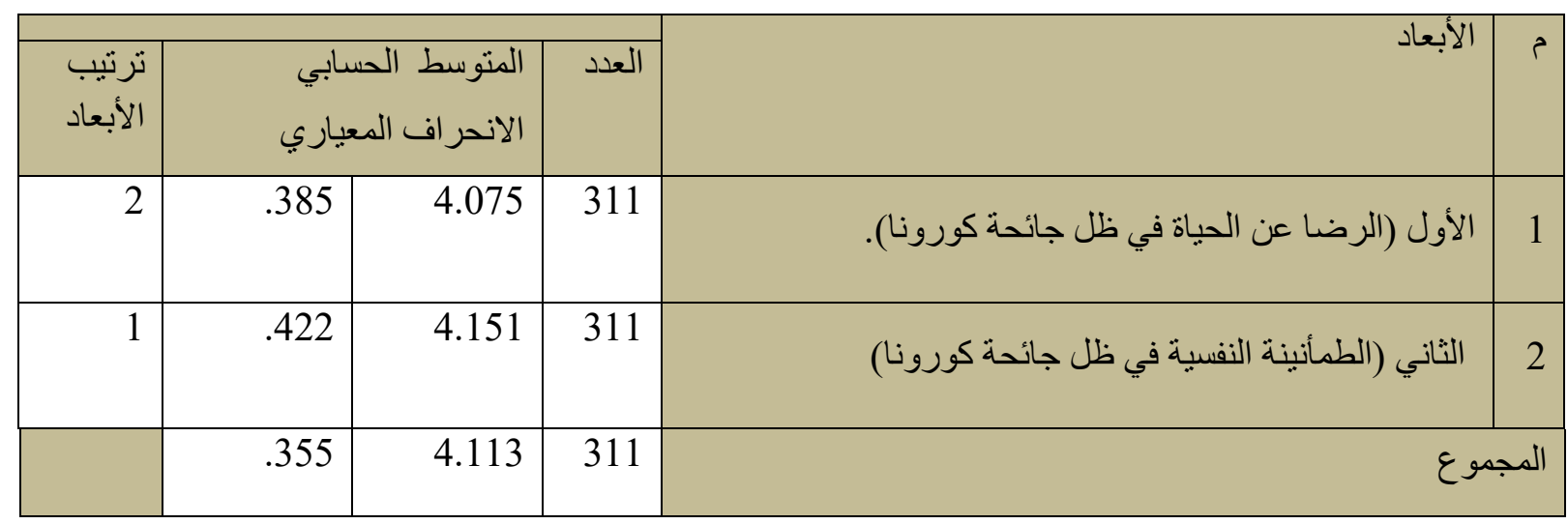

يعرض الجدول(2) نتائج تحليل استجابات أفر اد العينة حول مستوى الثعور بالأمن النفسي في المجتمع العماني، ويتضح أن المتوسطات الحسابية تراوحت بين (4.113 - 4.075)، و الانحر افات المعيارية (422. -

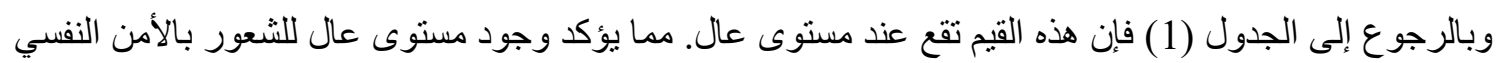
لاى المجتمع العماني ويعزو الباحثان ذلك إلى الجهود التي تبذلها اللجنة العليا المكلفة ببحث آلية التعامل مع التطورات الناتجة عن انتشار فيروس كورونا كوفيد 19، و التي تشكلت بأو امر سامية من لدن جلانلة السلطان هيثم بن طارق آل سعيد

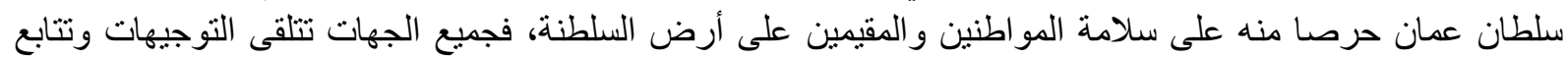
تنفيذها على مستوى المحافظات و الو لايات و الأسر و الأفر اد في المجتمع؛ لتوفير الاحتياجات الأساسية والضرورية لحياة التهات 
الأفر اد، و المحافظة على سلامنهم، وحمايتهم من الإصابة بهذا الفيروس و الذي انعكس على حباة الأفر اد وشعور هم بالأمن النفسي، هذا ما يؤكد وجود مسنوى عال للشعور بالأمن النفسي لدى الإنة المو اطن العماني.

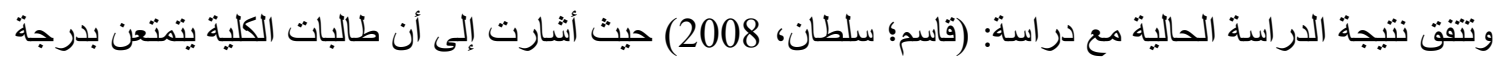

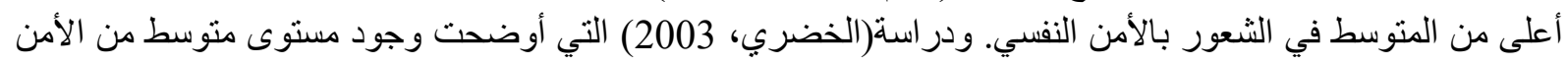

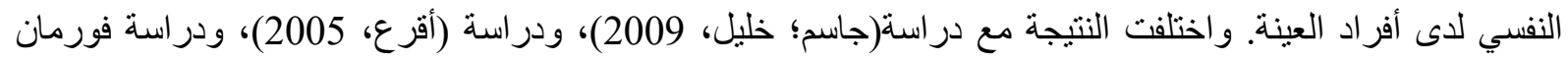

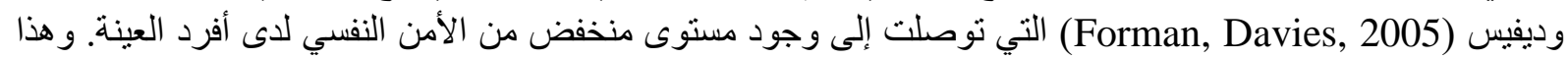

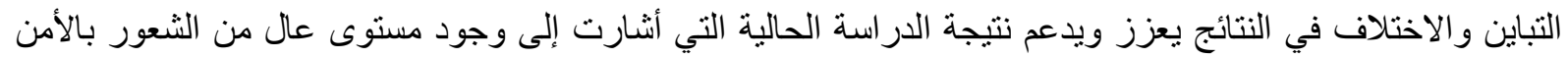

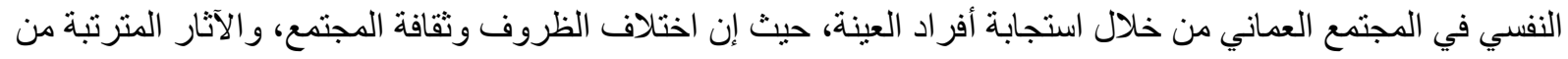

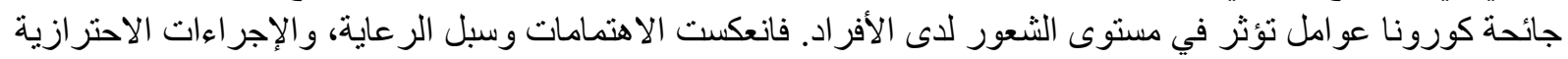

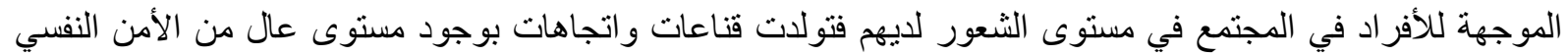
و هذا ما أشارت إليه النتائج.

ويلاحظ من الجدول السابق ترتيب أبعاد الأمن النفسي حسب استجابات أفر اد العينة حيث جاء البعد الثاني (الرضا

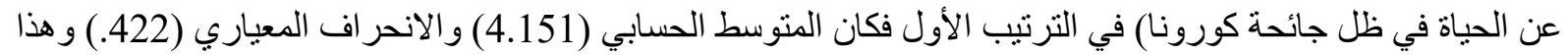

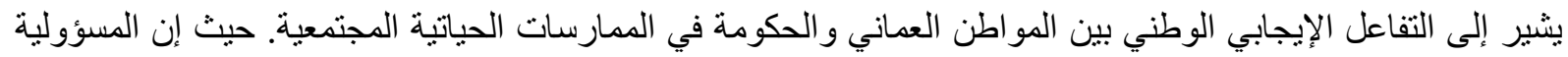

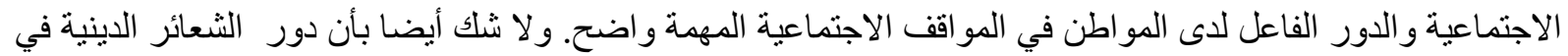

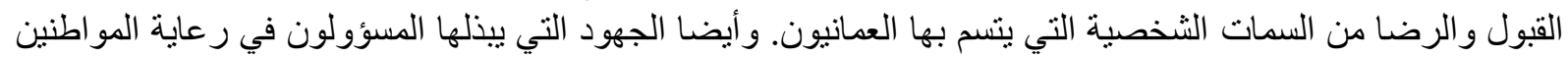

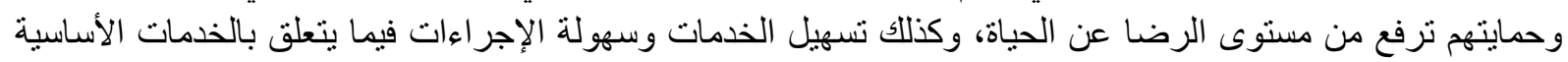

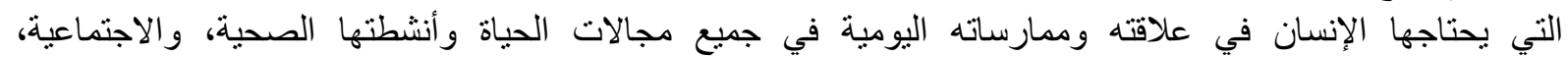
و الاقتصادية، و التعليمية و غير ها.

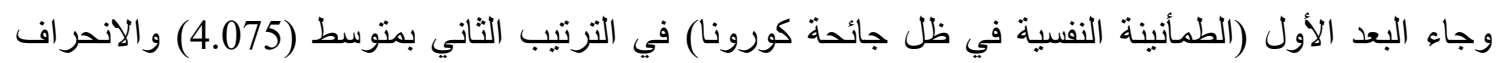

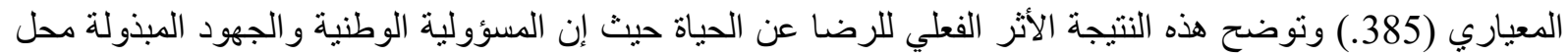

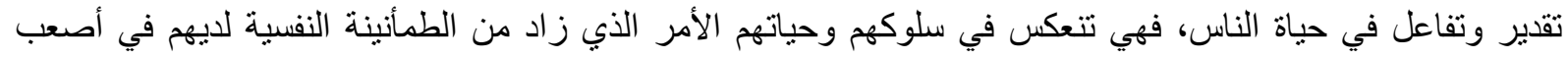
الظروف. وتعرض الجداول (3)، (4)، ترتيب فقرات فئ الاستبانة حسب استجابات العينة، وفق الأبعاد.

\begin{tabular}{|c|c|c|c|c|c|}
\hline 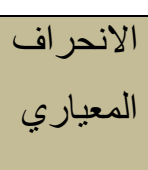 & الحسبط المسبي & 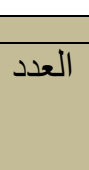 & 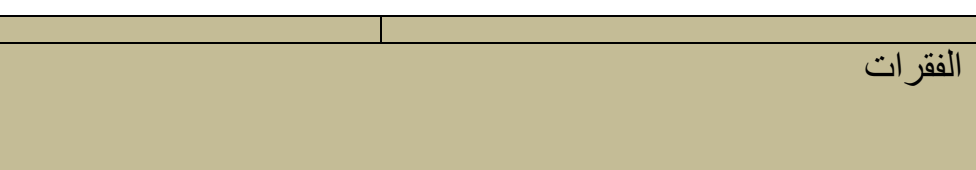 & ترتيب & $\ddot{ت}$ \\
\hline .6628 & 4.324 & 311 & أتقبل التوجيهات الداعية إلى المحافظة على نفسي من فيروس كورونا. & 5 & 1 \\
\hline 1.191 & 3.012 & 311 & أثق في قدرتي على حماية نفسي و أسرتي من هذه الجائحة. & 10 & 2 \\
\hline .4796 & 4.768 & 311 & أرى أن الحياة تسير من سيء إلى أسو أ في ظل هذه الجائحة. & 1 & 3 \\
\hline 1.170 & 3.263 & 311 & وجودي بين أفر اد أسرني يشعرني بالأمان و الاطمئنان في حياتي. & 9 & 4 \\
\hline .5900 & 4.636 & 311 & أشعر أن حياتي في الوقت الحالي أفضل من الماضي. & 4 & 5 \\
\hline 1.101 & 3.752 & 311 & ينتابني شعور بالبهجة و السرور في حياتي وأنا بالقرب من عائلتي. & 7 & 6 \\
\hline .5619 & 4.739 & 311 & كورداد اللوم والعتاب لنفسي ولأسرتي من حين لآخر حفاظا من فيروس & 2 & 7 \\
\hline 1.165 & 3.549 & 311 & أنشعر بالحزن و الألم عند ارتفاع عدد المصابين بفيروس كورونا. & 8 & 8 \\
\hline .7947 & 4.025 & 311 & أشعر بالانزعاج الثديد لانعز الي عن الجميع. & 6 & 9 \\
\hline .5361 & 4.684 & 311 & أشُعر بزيادة مقومات الثقة بالنفس في حياتي في ظل هذه الظروف. & 3 & 10 \\
\hline
\end{tabular}

جاول (3) يبين ترتيب فقرات الاستبانة وفق المتوسطات الحسابية والانحرافات المعيارية لاستجابات العينة في البعد الأول(الرضا عن الحياة في ظل جائحة كورونا) 
يتضح من خلال الجدول رقم (3) استجابات العينة على فقرات الاستبانة، و الترتيب الذي حصلت عليه كل فقرة من

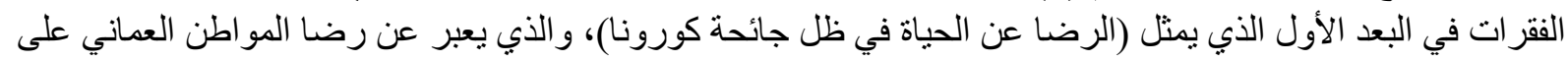

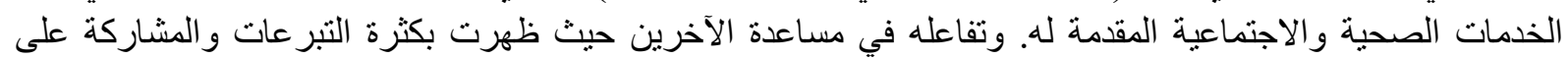

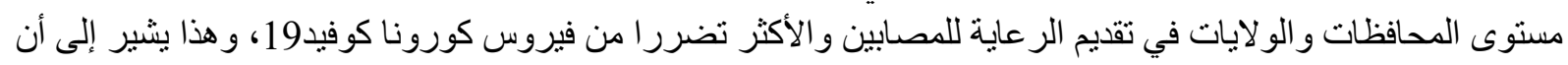

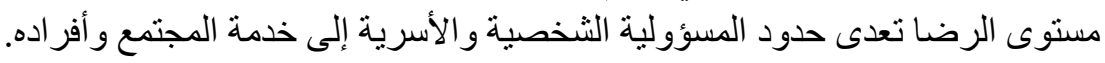

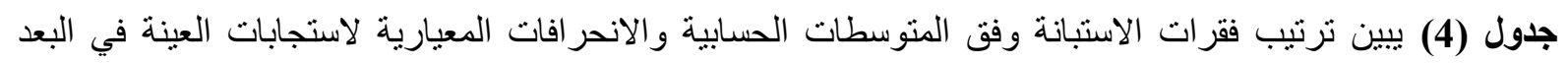

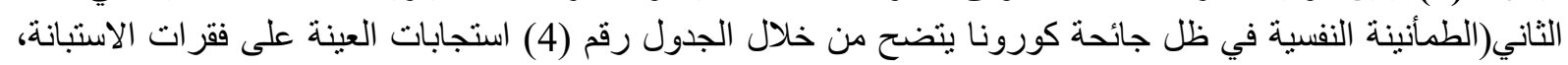

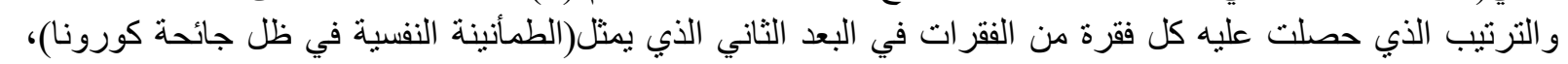

\begin{tabular}{|c|c|c|c|c|c|}
\hline الالمعراف & الحسابي & العدد & 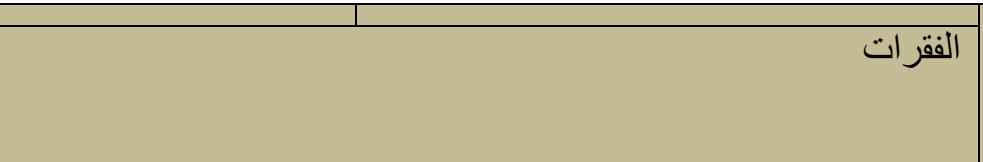 & ترتيب & $ت$ \\
\hline .6921 & 4.347 & 311 & تشعرني قيمي الدينية و عبادتي بالأمن و الاطمئنان في ظل جائحة كورونا. & 4 & 1 \\
\hline .6600 & 4.453 & 311 & أقدر تعاطف الجميع في مثل هذه الظروف. & 3 & 2 \\
\hline .6364 & 4.475 & 311 & أنشعر بالقدرة على التحمل و الصبر لمو اجهة جائحة كورونا. & 2 & 3 \\
\hline 1.070 & 3.662 & 311 & أتجنب الوقوع في الإحباط النفسي و الانهز امية في ظل هذه الجائحة. & 9 & 4 \\
\hline .6609 & 4.209 & 311 & الجائحة. شعوري بالحيوية و النشاط أثناء مشاركتي لأفر اد أسرتي في ظل هذه & 6 & 5 \\
\hline .7436 & 4.257 & 311 & أطمئن للمستقبل أكثر من الحاضر في ظل هذه الجائحة. & 5 & 6 \\
\hline 1.107 & 3.398 & 311 & أتمتع بحسن التصرف في ظل جائحة كورونا. & 10 & 7 \\
\hline .8194 & 4.077 & 311 & أحرص على أداء عملي رغم وجود المعوقات بسبب جائحة كورونا. & 7 & 8 \\
\hline .9333 & 3.945 & 311 & أشعر بعدم الارتياح و عدم الهدوء النفسي في ظل هذه الظروف. & 8 & 9 \\
\hline .6073 & 4.691 & 311 & ظلأستُر هذر الجائحة. لتطوير معارفي ومهار اتي للحصول على أفضل النتائج في & 1 & 10 \\
\hline
\end{tabular}

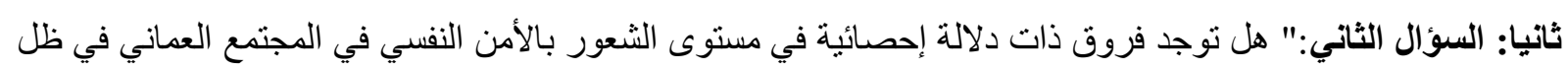

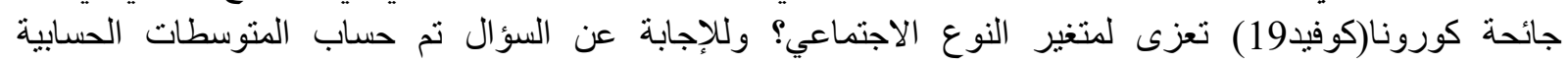

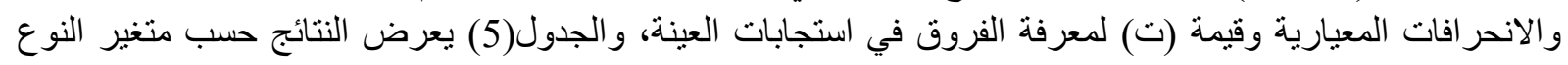




\begin{tabular}{|c|c|c|c|c|c|c|c|}
\hline \multirow{2}{*}{ الإحصائية } & \multirow{2}{*}{ قالمحسة (ت) } & \multicolumn{2}{|c|}{ إناث = 154} & \multicolumn{2}{|c|}{ ذكور ن=157 } & & \multirow[t]{2}{*}{ الأبعاد } \\
\hline & & $\varepsilon$ & r & $\varepsilon$ & 5 & & \\
\hline .811 & .239 & .428 & 4.081 & .339 & 4.070 & البعد الأول & استبانه \\
\hline .498 & .678 & .471 & 4.168 & .368 & 4.135 & البعد الثاني & الشعور \\
\hline .595 & .532 & .401 & 4.124 & .305 & 4.103 & المجموع الكلي & النفسي \\
\hline
\end{tabular}

جدول (5) المتوسطات الحسابية و الانحر افات المعيارية وقيمة (ت) لاستجابات العينة حسب متغير النوع الاجتماع

يتضح من الجدول (5) أن نتائج الدارسة تثنير إلى أن مستوى الثتعور بالأمن النفسي في ظل جائحة كورونا في التهي

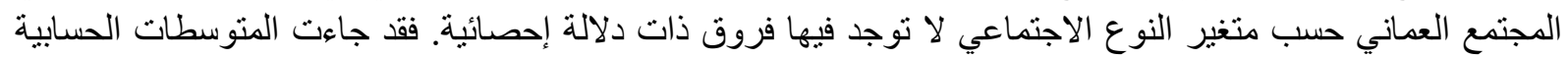

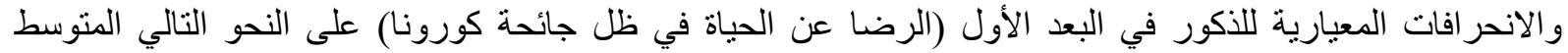

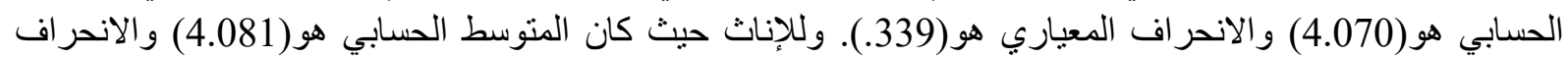

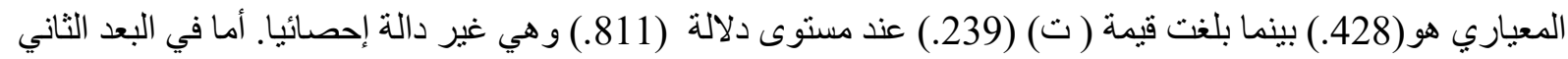

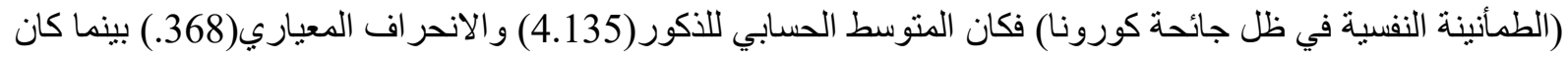

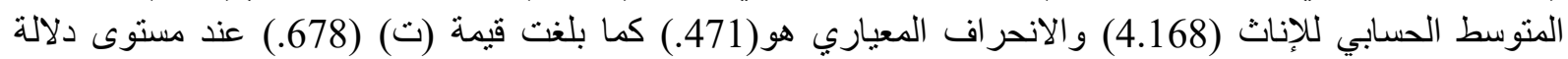

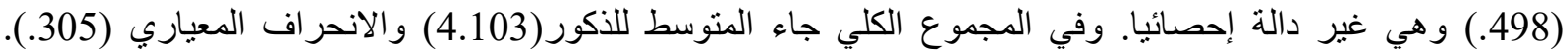
وللإناث كان المتوسط الحسابي (498.124) و والانحر اف المعياري (401.

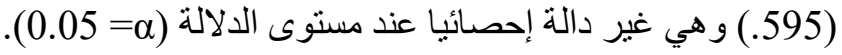

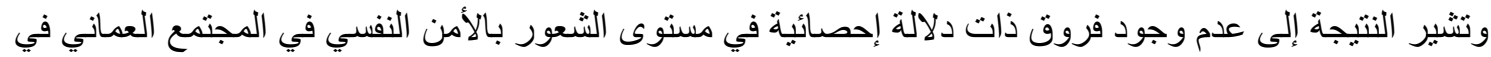

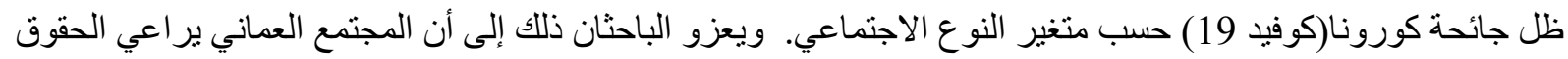

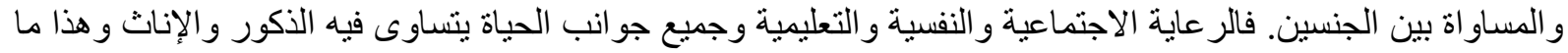

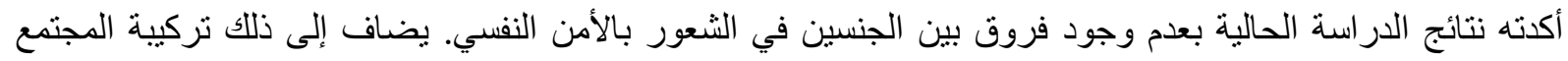

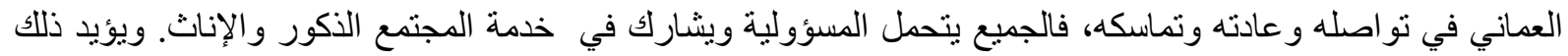
الاستقر ار الأسري والتو اصل المجتمعي الذي يعيشه المو اطن العماني والمقيم في السلطنة.

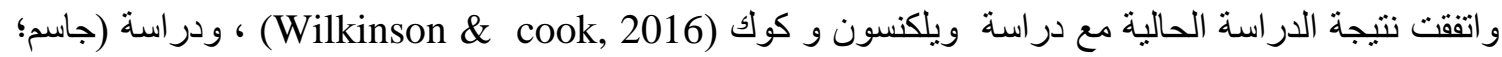

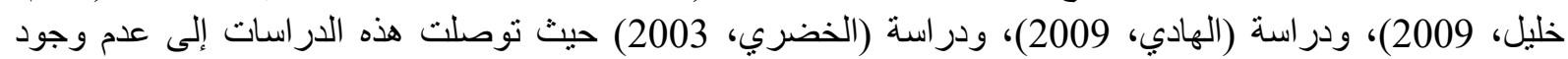

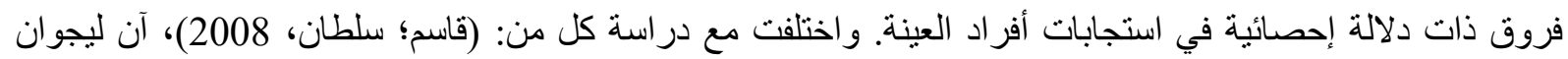

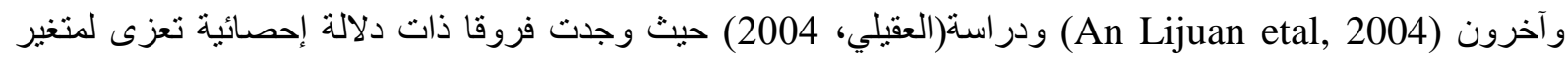

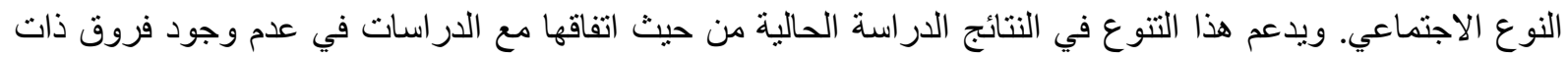
دلالة إحصائية في استجابات عينة الدر اسة تعزى لمتغير النوع الاجتماعي.

ثالثا: السؤال الثالث: هل توجد فروق ذات دلالة إحصائية في مستوى الثعور بالأمن النفسي لاى المجتمع العماني في ظل

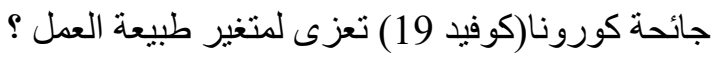

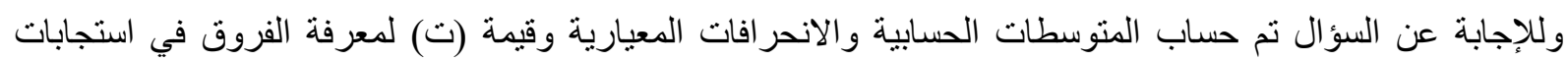
العينة، و الجدول(6) يعرض النت النتائج حسب منغير طبيعة العمل. 


\begin{tabular}{|c|c|c|c|c|c|c|c|}
\hline \multirow[t]{2}{*}{ الإحصائية } & \multirow[t]{2}{*}{ قيمة (ت) } & \multicolumn{2}{|l|}{$\begin{array}{l}=ن \\
157\end{array}$} & \multicolumn{2}{|c|}{ موظف } & \multirow[t]{2}{*}{ الأبعاد } & \multirow{5}{*}{ استبانه قياس الثنعور } \\
\hline & & $\varepsilon$ & 5 & $\varepsilon$ & s & & \\
\hline .077 & 1.775 & .363 & 4.037 & .404 & 4.114 & الأول & \\
\hline .003 & 3.028 & .427 & 4.080 & .405 & 4.224 & الثاني & \\
\hline .006 & 2.762 & .341 & 4.059 & .361 & 4.169 & المجموع الكلي & \\
\hline
\end{tabular}

جدول (6) المنوسطات الحسابية والانحر افات المعيارية وقيمة (ت) لاستجابات العينة حسب متغير طبيعة العمل

يتضح من الجدول (6) أن نتائج الدارسة تشير إلى أن مستوى الثتعور بالأمن النفسي لدى المجتمع العماني في ظل إنل

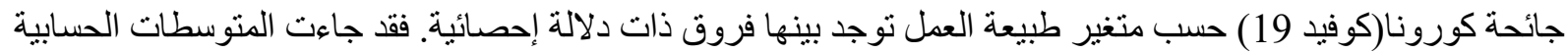

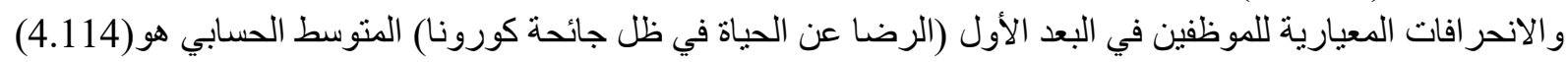

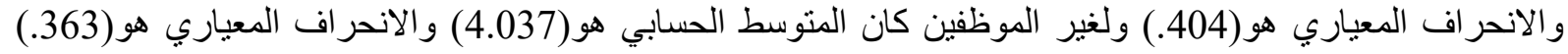

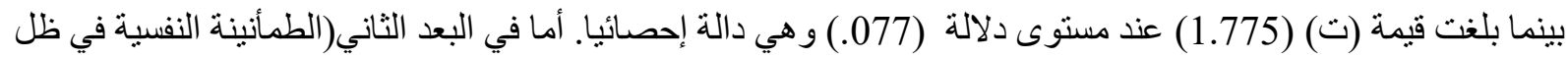

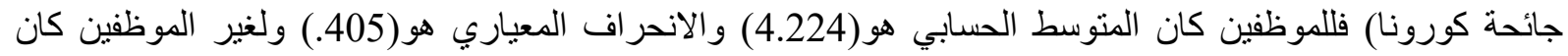

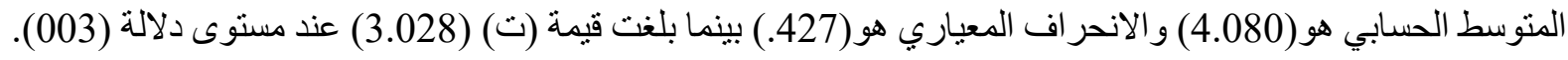

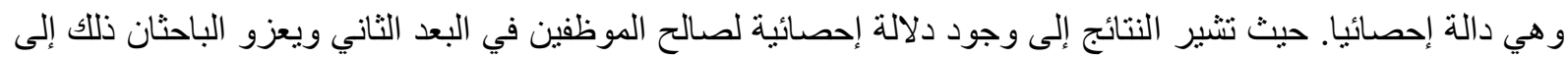

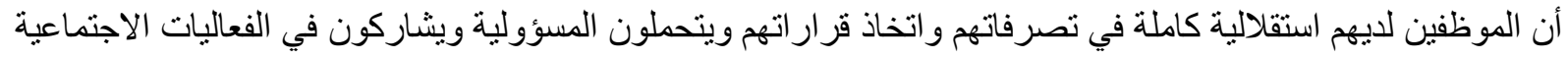

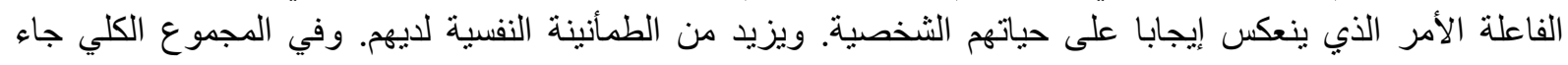

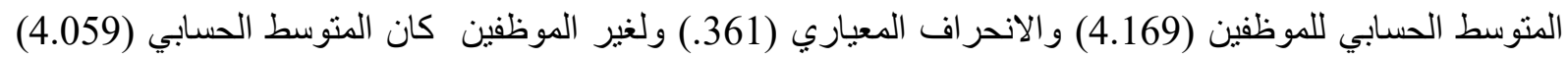

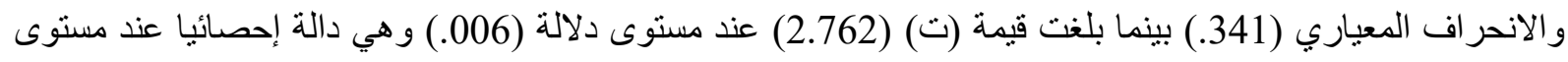

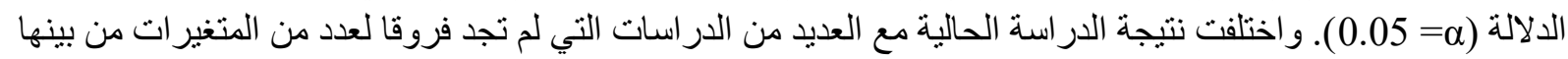

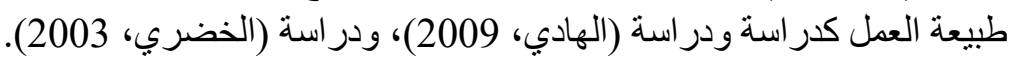

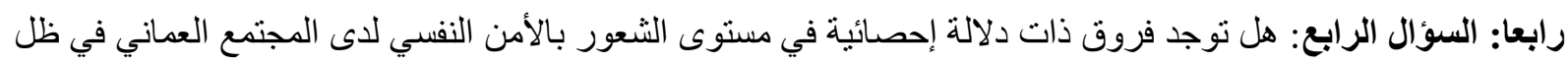

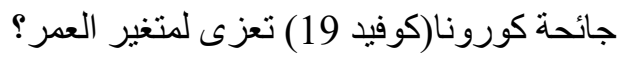
وللإجابة عن السؤال الخامس تم استخدام تحليل التباين الأحادي لدلالة الفروق بين المنتوسطات في استجابات العينة وفق متغير العمر، و الجدول(7) يعرض النوال النتائج حسب متغير العمر. 
جذول (7) تحليل التباين الأحادي لدلالة الفروق بين المتوسطات وفق متغير العمر

\begin{tabular}{|c|c|c|c|c|c|c|}
\hline مستوى & قمية (ف) & متوسط & درجة & مجموع المربعات & مصدر التباين & المتغير \\
\hline \multirow{3}{*}{.012} & \multirow{3}{*}{4.486} & .653 & 2 & 1.305 & بين المجموعات & \multirow{3}{*}{ الأول } \\
\hline & & .145 & 308 & 44.804 & في المجمو عات & \\
\hline & & & 310 & 46.109 & المجموع & \\
\hline \multirow{3}{*}{.564} & \multirow{3}{*}{.573} & .102 & 2 & .205 & بين المجمو عات & \multirow{3}{*}{ الثاني } \\
\hline & & .179 & 308 & 55.052 & في المجمو عات & \\
\hline & & & 310 & 55.257 & المجموع & \\
\hline \multirow{3}{*}{.130} & \multirow{3}{*}{2.056} & .258 & 2 & .517 & بين المجمو عات & \multirow{3}{*}{ الكلي } \\
\hline & & .126 & 308 & 38.714 & في المجمو عات & \\
\hline & & & 310 & 39.231 & المجموع & \\
\hline
\end{tabular}

بتضح من الجدول (7) أن قيمة (ف) في البعد الأول (4.486) عند مستوى دلالة (012.) وهي دالة إحصائبا، بينما

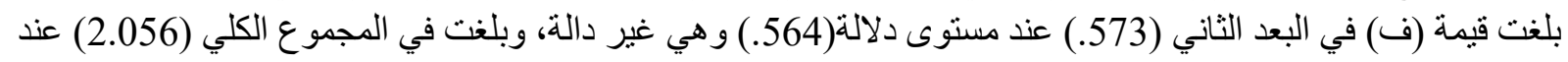

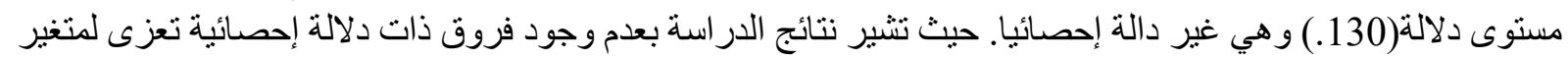

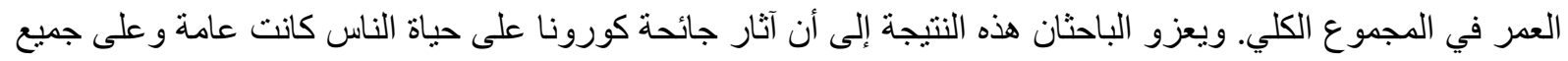

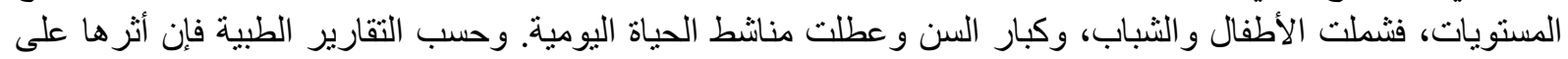

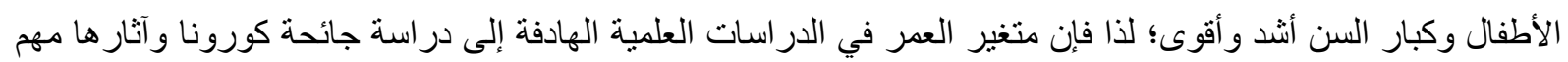

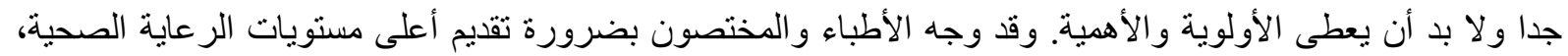

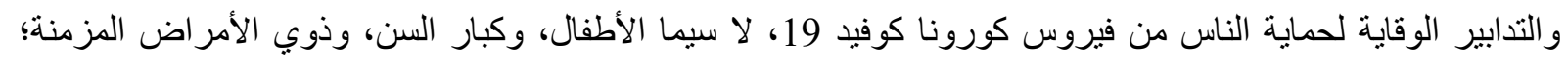

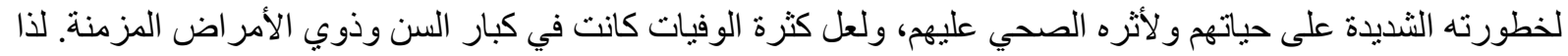

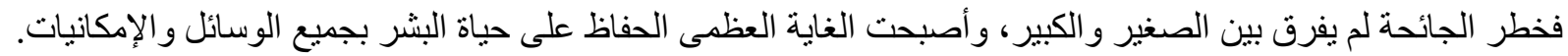

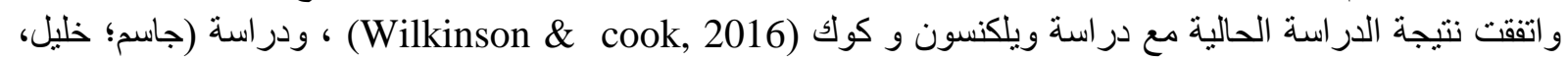
2009)، (العقيلي، 2004) التي توصلت إلى عدم وجود فروق ذات دلالة إحصائية في عدد من المتغير اتل 
1 - إجراء المزيد من البحوث والدراسات للتعرف على عوامل تعزيز الثعور بالأمن النفسي وأثره على حياة الأفراد باستخدام أدو ات ومقاييس جديدة وبمتغير ات متنو عة ومتعددة في ظل هذه الجائحة.

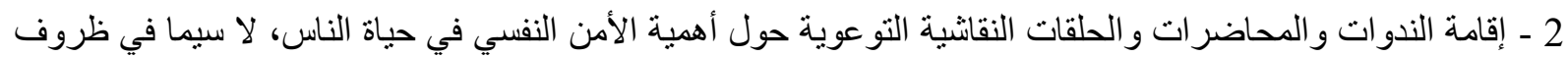

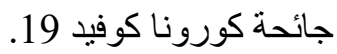
3 - الاستفادة من مراكز الإرشاد النفسي والاجتماعي ومراكز الاستشارات الأسرية في تنمية المجتمع بجميع فئاته

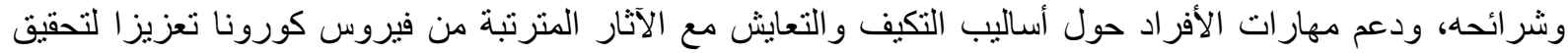
مستويات من الأمن النفسي. 4 ـ تعزيز الثعور بالأمن النفسي لدى الآباء والأمهات من خلال التعرف على احتياجاتهم، واحتياجات أبنائهم في ظل جائحة كورونا.

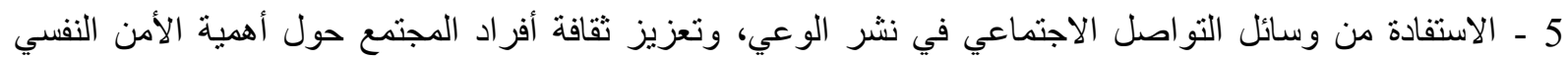

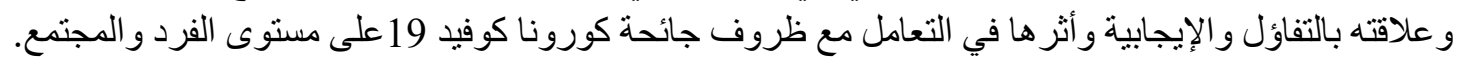

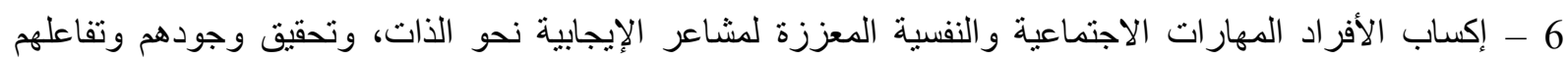
اجتماعيا ونفسيا في ظل جائحة كورونا من خلال الورش والدأل المؤتمر ات التباعدية باستخدام التقنيات الإلكترونية الحديثة.

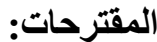

1 - دراسة التو افق المهني و علاقته بالأمن النفسي لاى العاملين بمؤسسات المجتمع المدني بسلطنة عمان في ظل جائحة

2 - در اسة علاقة الأمن النفسي بالحاجات النفسية لدى طلبة الجامعات بسلطنة عمان في ظل جائحة كورونا. برنامج مقترح لتعزيز مستوى الثعور بالأمن النفسي لاى طلبة التعليم الأساسي بسلطنة عمان في ظل جائحة كورونا كوفيد

3 - در اسة الأمن النفسي و علاقته بالضغوط الأكاديمية و القلق و الاكتئاب لدى طلبة الجامعة بسلطنة عمان في ظل جائحة كورونا. 4 - (در اسة مقارنة) مستوى الثعور بالأمن النفسي و علاقته ببعض المتغير ات في المجتمع العماني بعد جائحة كورونا. 
الآغا، كاظم ولي(1988). القلق و التحصيل الدراسي: دراسة تجريبية مقارنة لعلاقة القلق بالتحصيل الدراسي لدى الذكور

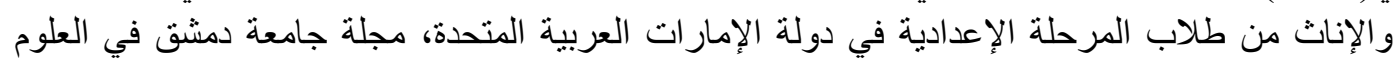

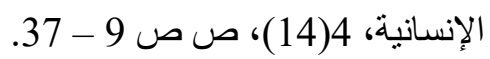

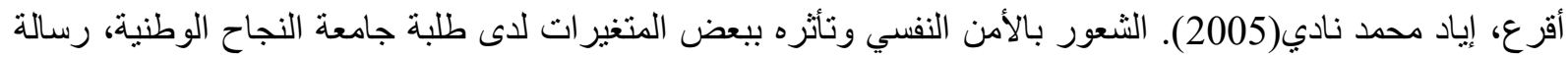

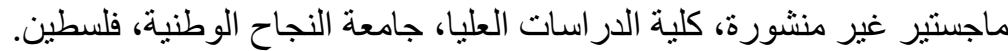

جابر، عبد الحميد جابر(1995). نظريات الشخصية، ط 1، دارية دار النهضة العربية، القاهرة.

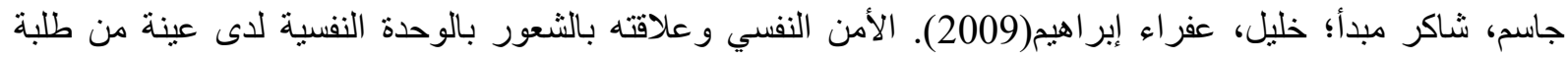

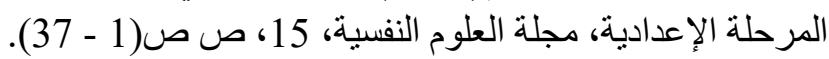

جبر، محمد جبر(1996). بعض المتغير ات الديمو غر افية المرتبطة بالأمن النفسي، مجلة علم النفس، الهيئة المصرية العامة

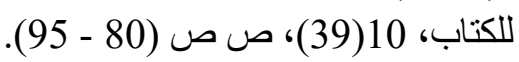

جمال، بهيجة (1998). العلاقة بين الضغوط الوالدية وسمتي القلق والاكتئاب عند الأطفال كما تدركها الأمهات العاملات

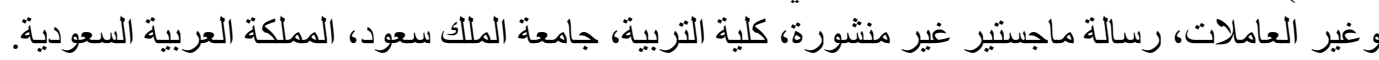
حليم، شيري مسعد(2017). الطمأنينة الانفعالية لدى طلبة الجامعة و علاقتها بالتو افق الاجتماعي و الضغوط الأكية الكاديمية

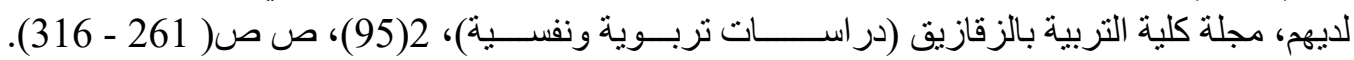
حنون، رسمية (2001). مفهوم الذات لاى طلبة جامعة النجاح الوطنية في فلسطين، در اسات نفسية تربوية، 11(31)، ص صلفية ص ص 32 - 32

خضر، بثينة تيم عبد الرحمن(2013). مقترحات ممأسسة لتعزيز الأمن النفسي والاجتماعي لموظفي وزارة الثؤون

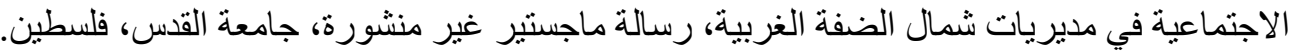

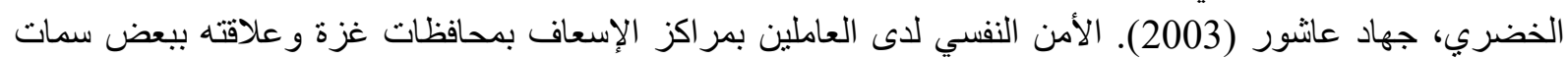

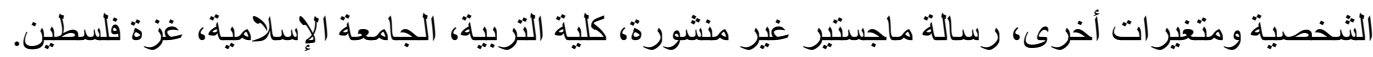

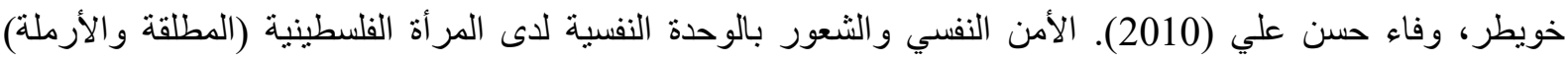

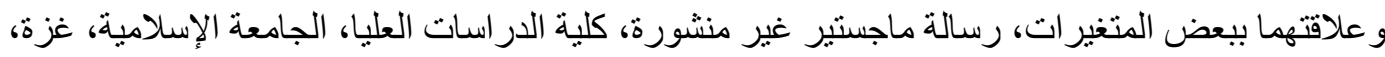

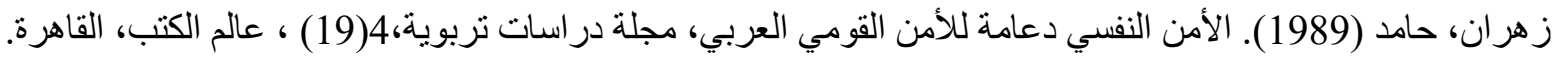

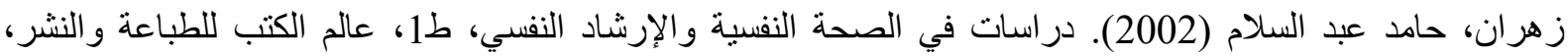
القاهرة.

زيداني، سعيد (2002) فصلية حقوق الإنسان الفلسطينيين، العدد (10)، فلسطين.

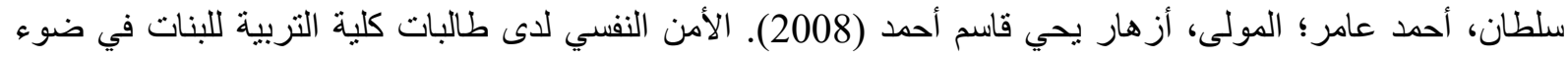

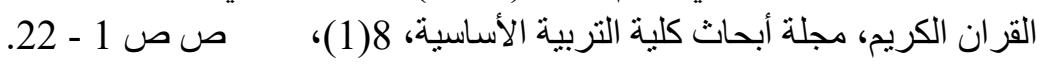

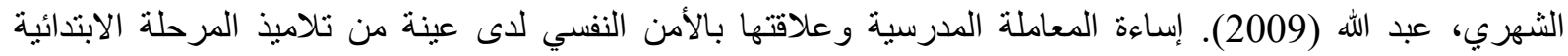

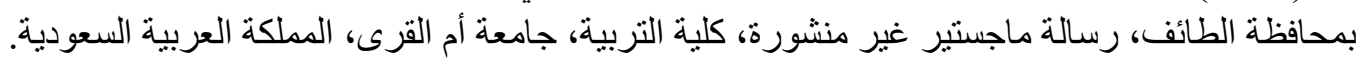

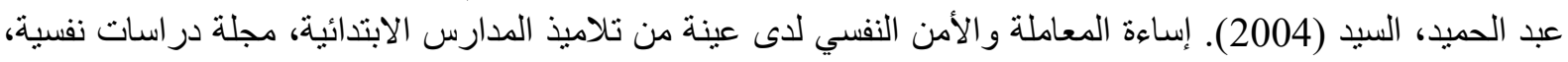

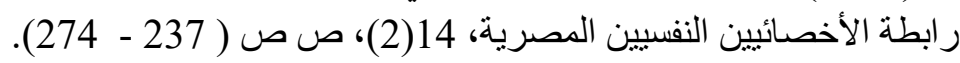

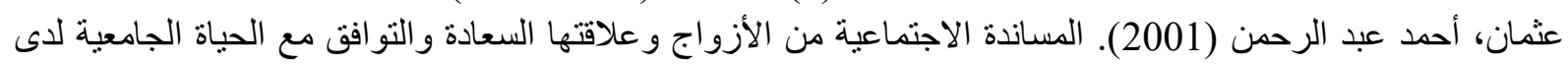

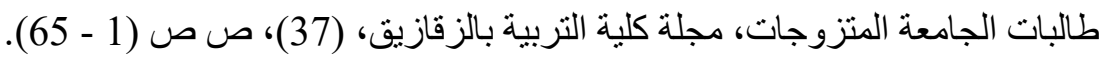
العزة، سعيد حسني؛ عبدالهادي، جودت عزت (1999). نظريات الإرشاد و العلاج النفسي، ط1، الني، مكتبة دار الثقافة للنشر و التوزيع، عمان، الأردن.

عسيري، عبير (2003). علاقة تنكل هوية الأنا بكل من مفهوم الذات و التوافق النفسي و الاجتماعي و العام لدى عينة من

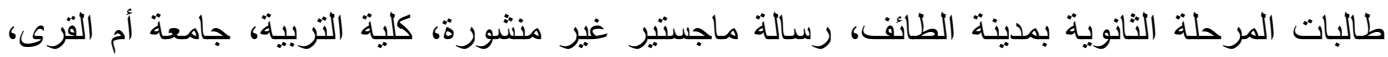
المملكة العربية السعودية.

العقيلي، عادل (2004). الاغتراب و علاقته بالأمن النفسي لدى طلبة جامعة الإمام محمد بن سعود الإسلامية بمدينة

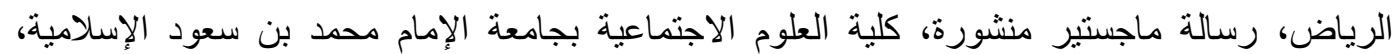

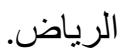




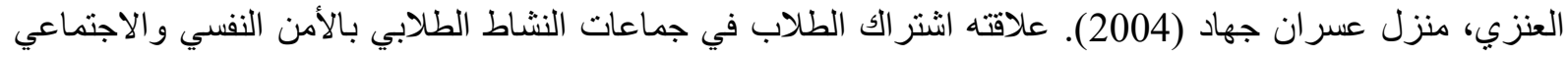
لدى طلاب المرحلة الثانوية بمدينة الرياض، رسالة ماجستير غير منشورة، كلية الدراسات العليا، جامعة الإنة

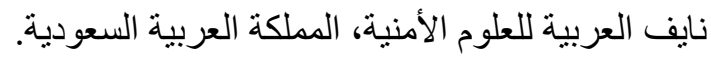

فروجه، بلحاج (2011). التو افق النفسي والاجتماعي وعلاقته بالدافعية للتعلم لدى المر اهق المتمدرس في التعليم الثانوي،

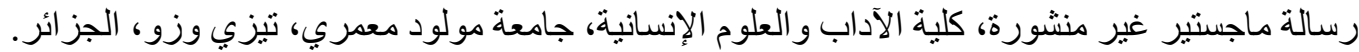

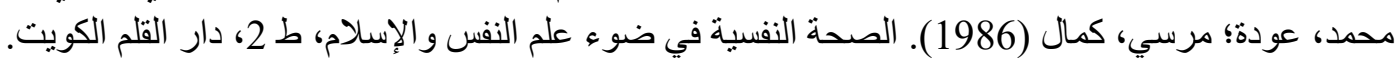

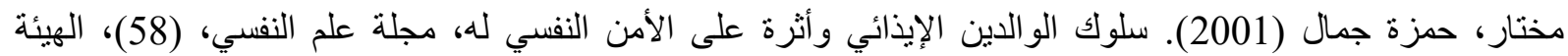
المصرية العامة للكتاب، ص صل صل (128) (143).

نعيسة، رغداء (2014). مستوى الثعور بالأمن النفسي وعلاقته بالتوافق الاجتماعي، مجلة جامعة دمشق، 30(2)، ص ص ص (125-81). (125). (1) (20)

الهادي، مروة (2009). الأمن النفسي و علاقته بالصلابة النفسية لاى المر اهقين ذوي الإعاقة السمعية (در اسة سيكومثرية

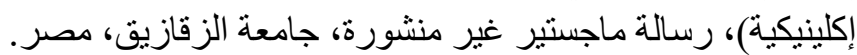

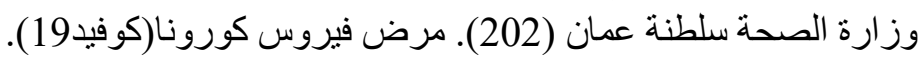
https://www.moh.gov.om/corona

Forman, E., M., \& Davies, p., T. (2005). Assessing appraisals of security in the family system the development of the security in the family system. Journal of child psychology and psychiatry, 46(8), p.p $900-916$.

Kerns, K., \& Aspelmmeier, J., \& Grabill, C. (2001). Parent- Child Attachment and Monitoring in middle Childhood. Journal of Family Psychology, 15(1), P.P $(9-81)$.

Lijuan, An; Zhong, C., \& Xin., W. (2004). Research of high school students, security and the related factors, Chines mental health, 18(10), P.P 717-719

Wilkinson, K., \& cook, E., (2016). Stress respose and emotional security in the intergenerational transmission of depressire symptons. Journal of child \& Adolescent, 4(1), p.p(1-9). 